\title{
Three new genera of rhinebothriidean cestodes from stingrays in Southeast Asia
}

\author{
Janine N. Caira ${ }^{1}$, Claire J. Healy ${ }^{2}$, Fernando P.L. Marques ${ }^{3}$ and Kirsten Jensen ${ }^{4}$ \\ ${ }^{1}$ Department of Ecology and Evolutionary Biology, University of Connecticut, Storrs, Connecticut, USA; \\ ${ }^{2}$ New Paltz, New York, USA; \\ ${ }^{3}$ Departamento de Zoologia - IB, Universidade de São Paulo, Cidade Universitária, São Paulo-SP, Brazil; \\ ${ }^{4}$ Department of Ecology and Evolutionary Biology and the Biodiversity Institute, University of Kansas, Lawrence, Kansas, USA
}

\begin{abstract}
Three genera of rhinebothriideans, previously referred to as New genus 1, New genus 2 and New genus 4, are erected in the the Anthocephaliidae. New genus 1 is established as Divaricobothrium gen. n., with Divaricobothrium tribelum sp. n. as its type species; Echeneibothrium trifidum Shipley et Hornell, 1906 is transferred to the genus as Divaricobothrium trifidum (Shipley et Hornell, 1906) comb. $n$. This genus is unique among rhinebothriidean genera in bearing bothridia that are posteriorly deeply divided into two lobes with facial loculi but no apical sucker, and a vagina that extends to near the anterior margin of the proglottid. Its species parasitise Indo-Pacific members of the genera Brevitrygon Last, Naylor et Manjaji-Matsumoto, Maculabatis Last, Naylor et Manjaji-Matsumoto and Pateobatis Last, Naylor et Manjaji-Matsumoto. New genus 2 is established as Barbeaucestus gen. n., with Barbeaucestus jockuschae sp. n. as its type species; Barbeaucestus ralickiae sp. n. is also described. Anthobothrium sexorchidum Williams, 1964 and Rhinebothrium shipleyi Southwell, 1912 are transferred to the genus as Barbeaucestus sexorchidus (Williams, 1964) comb. n. and Barbeaucestus shipleyi (Southwell, 1912) comb. n., respectively. This genus is unique among rhinebothriidean genera in that its bothridia are substantially wider than long, bear an apical sucker and at least one row of two or more facial loculi in their anterior half. Its species parasitise the genera Neotrygon Castelnau and Taeniura Müller et Henle. New genus 4 is established as Sungaicestus gen. n. with transfer of Rhinebothrium kinabatanganensis Healy, 2006, as Sungaicestus kinabatanganensis (Healy, 2006) comb. n., as its type species. Among the genera of its order, this genus most closely resembles Rhinebothrium Linton, 1890, however, despite the original description, the bothridia were found to bear, rather than lack, apical suckers. This monotypic genus is known only from the freshwater stingray Urogymnus polylepis (Müller et Henle). The familial diagnosis of the Anthocephaliidae Ruhnke, Caira et Cox, 2015 is emended. The family now houses five genera.
\end{abstract}

Keywords: tapeworms, taxonomy, freshwater, Rhinebothriidea, Dasyatidae, batoids, new species, Anthocephaliidae

In her dissertation treating the systematics of Rhinebothrium Linton, 1890 and its relatives, Healy (2006a) described, but did not formally name, four new genera of rhinebothriidean tapeworms. Data beyond the substantial morphological and preliminary molecular evidence she originally presented attesting to the unique nature of all four genera have continued to accumulate since that time. All subsequent more expanded molecular phylogenetic studies including these genera have supported their novelty (Healy et al. 2009, Caira et al. 2014, Ruhnke et al. 2015, Marques and Caira 2016). As recommended by Article 8 of the ICZN (1999), Healy (2006a) disclaimed the names she proposed for these taxa in her dissertation. As a consequence, they have been referred to in the molecular studies cited above with the informal names: New genus 1 , New genus 2, New genus 3 and New genus 4. Reyda et al. (2016) recently erected Stillabothrium Healy et Reyda, 2016 in the family Escherbothriidae Ruhnke, Caira et Cox, 2015 for New genus 3. Here we erect the anthocephaliid genera Divaricobothrium gen. n. for New genus 1, Barbeaucestus gen. n. for New genus 2 and Sungaicestus gen. n. for New genus 4 for three novel species and four previously described species transferred to these genera.

\section{MATERIALS AND METHODS}

Each of the three new species described here was found parasitising a different species of stingray in the coastal waters of Borneo. The host specimens from which these species were collected are as follows:

Neotrygon orientale Last, White et Séret (= Neotrygon kuhlii 1 of Naylor et al. 2012): 1 male and 1 female (disk width [DW] $23 \mathrm{~cm}$ and $30 \mathrm{~cm}$; BO-336 and BO-338, respectively) collected

Address for correspondence: J. N. Caira, University of Connecticut, Department of Ecology and Evolutionary Biology, 75 N. Eagleville Rd., Unit 3043, Storrs, Connecticut, USA. 06269-3043. Phone: +1-860-486-4060; Fax:+1-860-486-6364; E-mail: janine.caira@uconn.edu

Zoobank number for article: urn:lsid:zoobank.org:pub:B8D70A0B-8480-4D91-BFBB-072377722950 
28 April 2004 in the South China Sea off Kuching (02³0'07"N; $110^{\circ} 40^{\prime} 17^{\prime \prime E}$ ), Sarawak, Malaysia and 1 female (DW $29 \mathrm{~cm}$; BO321) collected 27 May 2003 in the South China Sea off Pulau Balambangan $\left(07^{\circ} 16^{\prime} 29^{\prime \prime} \mathrm{N} ; 116^{\circ} 56^{\prime} 25^{\prime \prime} \mathrm{E}\right)$, Sabah, Malaysia.

Taeniura lymma 1 sensu Naylor et al. (2012): 2 males and 1 female (DW $16 \mathrm{~cm}, 23 \mathrm{~cm}$ and $24 \mathrm{~cm}$; BO-123, BO-130 and BO-128, respectively) collected 5 May 2003 in the Celebes Sea off Pulau Mabul (0414'44"N; 118³7'53"E), Sabah, Malaysia, 1 female (DW $24 \mathrm{~cm}$; BO-80) collected 25 June 2002 off Kunak

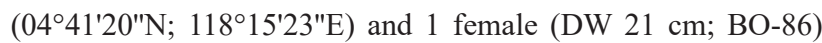
collected 27 June 2002 off Semporna (04²8'44"N; $\left.118^{\circ} 37^{\prime} 01^{\prime \prime E}\right)$, both in the Celebes Sea, Sabah, Malaysia, and 1 male (DW $29 \mathrm{~cm}$; KA-419) collected 25 July 2005 in the Sulawesi Sea off a reef near Pulau Rabu Rabu $\left(02^{\circ} 19^{\prime} 05^{\prime \prime N}\right.$; $\left.118^{\circ} 07^{\prime} 25^{\prime \prime E}\right)$, East Kalimantan, Indonesia.

Maculabatis gerrardi (Gray) (as Himantura cf. gerrardi 2 sensu Naylor et al. 2012): 1 male (DW $62 \mathrm{~cm}$; BO-23) collected 3 June 2002 in the South China Sea off Sematan $\left(01^{\circ} 48^{\prime} 15^{\prime \prime N}\right.$; $109^{\circ} 46^{\prime} 47^{\prime \prime E}$ ), Sarawak, Malaysia, 1 female (DW 62; BO-88) collected 28 June 2002 in the Celebes Sea off Tawau (04 $14^{\circ} 34^{\prime \prime N}$; $117^{\circ} 53^{\prime} 01^{\prime \prime E}$ ), Sabah, Malaysia and 1 female (DW $39 \mathrm{~cm}$; BO158) collected 14 May 2003 in the South China Sea off Sematan (0148'15"N; 10946'47"E), Sarawak, Malaysia.

The identities of all specimens of Neotrygon orientale (i.e. BO-321, BO-336 and BO-338), 4 of the 6 specimens of Taeniura lymma 1 (i.e. BO-123, BO-128, BO-130 and KA-419), and 2 of the 3 specimens of Maculabatis gerrardi (i.e. BO-158 and BO23) were confirmed (J.N.C., K.J. and H. Ralicki, University of Connecticut, Storrs, Connecticut, USA - pers. comm.). Additional information for and images of all host specimens are available in the Global Cestode Database (http://elasmobranchs.tapewormdb. uconn.edu) using the host specimen Collection Codes and Collection Numbers (e.g. BO-321). In each case, the body cavity was opened with a mid-ventral incision and the spiral intestine was removed and opened with a longitudinal incision. A subset of worms found was fixed in $10 \%$ formalin buffered in seawater; another subset was removed and fixed in $95 \%$ ethanol. The spiral intestine and the remaining worms were fixed in $10 \%$ formalin buffered in seawater. All formalin-fixed samples were transferred to $70 \%$ ethanol for storage after approximately 2 weeks.

Whole mounts were prepared according to standard techniques: specimens were hydrated in distilled water, stained with Delafield's hematoxylin, differentiated in tap water, destained in $70 \%$ acid ethanol, alkalinised in $70 \%$ basic ethanol, dehydrated in a graded ethanol series, cleared in methyl salicylate, and mounted in Canada balsam on glass slides under coverslips.

Specimens were prepared for scanning electron microscopy (SEM) as follows. They were hydrated in a graded ethanol series, post-fixed in $1 \%$ osmium tetroxide overnight, washed in distilled water, dehydrated in a graded ethanol series, transferred to hexamethyldisilizane for $20 \mathrm{~min}$, air-dried and mounted on aluminum stubs on double-sided adhesive carbon tape. Specimens were sputter-coated with $\sim 20-30 \mathrm{~nm}$ of gold/palladium and examined with a Nova NanoSEM 450 field emission scanning electron microscope at the Bioscience Electron Microscopy Laboratory at the University of Connecticut, Storrs, Connecticut, USA.

All measurements are given in micrometres $(\mu \mathrm{m})$ unless otherwise stated and are presented as the range followed in parentheses by the mean, standard deviation and number of worms examined.
Internal organ measurements are presented for the terminal proglottid only. Number and dimensions of testes, and dimensions of vitelline follicles were averaged within individuals. Images of specimens were taken with a SPOT Flex Camera mounted on a Zeiss Axioskop 2 Plus compound microscope and morphometric data were generated from these images using Wormbox v. 1.0 (https://github.com/nelas/WormBox) in ImageJ. Line drawings were prepared with the aid of a camera lucida attached to a Zeiss Axioskop 2 Plus compound microscope. Microthrix terminology follows Chervy (2009). Elasmobranch taxonomy follows Naylor et al. (2012) and Last et al. (2016a,b).

Museum abbreviations used are as follows: BMNH, Natural History Museum, London, UK; IPCAS, Institute of Parasitology, Biology Centre of the Czech Academy of Sciences, České Budějovice, Czech Republic; LRP, Lawrence R. Penner Parasitology Collection, Department of Ecology and Evolutionary Biology, University of Connecticut, Storrs, Connecticut, USA; MZB, Museum Zoologicum Bogoriense, Centre for Biology, Indonesian Institute of Science, Cibinong, Jakarta-Bogor, Java, Indonesia; MZUM(P), Muzium Zoologi, Universiti Malaya, Kuala Lumpur, Malaysia; SBC, Sarawak Biodiversity Centre, Kuching, Sarawak, Malaysia; SAM, South Australian Museum, Adelaide, South Australia, Australia; USNM, National Museum of Natural History, Smithsonian Institution, Washington, D.C., USA.

A loculus formula was developed for species of Barbeaucestus gen. $\mathrm{n}$. to facilitate comparison of locular configurations across species of the new genus. The formula is presented as: $(\mathrm{A})(\mathrm{C})(\mathrm{P})$, where A represents the number of loculi in the anterior-most row, $\mathrm{C}$ represents the number of loculi in the central row and $\mathrm{P}$ represents the number of loculi in the posterior-most row. If more than a single central row of loculi is present, $\mathrm{C}$ is given as a series of numbers separated by slashes. Thus (1)(4/6/6)(4) indicates a bothridium that bears a single loculus in the anterior-most row, 3 central rows with 4, 6 and 6 loculi, respectively, and a posterior-most row with 4 loculi.

\section{RESULTS \\ Barbeaucestus gen. n.}

ZooBank number for genus:

urn:lsid:zoobank.org:act:DE12E22E-B018-4DE7-AF6F-5943C06BD768

Informal synonym: New genus 2 of Healy et al. (2009), Caira et al. (2014), Ruhnke et al. (2015) and Marques and Caira (2016)

Diagnosis. Rhinebothriidea; Anthocephaliidae Ruhnke, Caira et Cox, 2015. Worms craspedote, euapolytic. Scolex with 4 bothridia and relatively short cephalic peduncle; myzorhynchus absent. Bothridia stalked, wider than long, with apical sucker and facial loculi; bothridial margins with thin velum. Loculi arranged in 3-5 rows; loculi of central row longer than loculi of anterior and posterior rows. Mature proglottids longer than wide. Testes numerous, arranged in 2-4 irregular columns anterior to cirrus sac. Vas deferens extending anteriorly from level of ovarian isthmus to enter cirrus sac at anterior margin, not expanded to form external seminal vesicle. Genital pores lateral, irregularly alternating; genital atrium shallow. Cirrus 
sac thin-walled, tilted posteriorly, containing coiled cirrus; cirrus armed with spinitriches. Vagina sinuous, extending from ootype along midline of proglottid to anterior margin of cirrus sac, then laterally to open into genital atrium anterior to cirrus sac; vaginal sphincter absent; seminal receptacle not observed. Ovary H-shaped in frontal view, tetralobed in cross section; ovarian margins lobulate. Vitellarium follicular; follicles distinctly wider than long, in 2 lateral bands; each band consisting of 2-4 columns of follicles, extending length of proglottid, interrupted by terminal genitalia, may be partially interrupted by ovary. Uterus median, ventral, sacciform, extending from ovarian isthmus to anterior margin of proglottid. Excretory vessels 4 , arranged in 1 dorsal and 1 ventral pair on each lateral margin of proglottid. Parasites of Dasyatidae (Myliobatiformes), Indo-Pacific Ocean.

Type species: Barbeaucestus jockuschae gen. n. et sp. n.

Additional species: Barbeaucestus ralickiae sp. n., Barbeaucestus sexorchidus (Williams, 1964) comb. n., and Barbeaucestus shipleyi (Southwell, 1912) comb. n.

Etymology: This genus honours Elizabeth Barbeau for her outstanding and tireless efforts to facilitate and support cestode work across the globe.

Remarks. Barbeaucestus gen. n. is unique among rhinebothriidean genera in its possession of bothridia that are conspicuously wider than long and bear an apical sucker as well as at least one row of two or more facial loculi in their anterior half. Barbeaucestus conspicuously differs further from Clydonobothrium Euzet, 1959, Echeneibothrium van Beneden, 1850, Notomegarhynchus Ivanov et Campbell, 2002, Phormobothrium Alexander, 1963, Pseudanthobothrium Baer, 1956 and Tritaphros Lönnberg, 1889 in lacking a myzorhynchus in the adult form. It can further be distinguished from Biotobothrium Tan, Zhou et Yang, 2009, Crassuseptum Eyring, Healy et Reyda, 2012, Rhinebothrium, Rhinebothroides Mayes, Brooks et Thorson, 1981, Rhodobothrium Linton, 1890, Scalithrium Ball, Neifar et Euzet, 2003 and Spongiobothrium Linton, 1889 in its possession, rather than lack, of an apical sucker on each bothridium. In this respect the new genus also differs from Zyxibothrium Hayden et Campbell, 1981, although the status of the latter genus as a rhinebothriidean remains uncertain.

Despite the fact that the bothridia of Rhabdotobothrium Euzet, 1953 were not formally described to bear apical suckers (see Euzet 1953), evidence of this feature in the genus is mounting (e.g. see fig. 14 in Healy et al. 2009). However, Rhabdotobothrium possesses bothridia that are horizontally divided into well over five, rather than 3-5, rows of loculi and possesses, rather than lacks, post-vaginal testes. The lack of marginal loculi throughout the perimeter of the bothridia further distinguishes Barbeaucestus from Anindobothrium Marques, Brooks et Lasso, 2001, Anthocephalum Linton, 1890 and Cairaeanthus Kornyushin et Polyakova, 2012.

Barbeaucestus most closely resembles Escherbothrium Berman et Brooks, 1994 and Stillabothrium. Beyond the differences in the arrangement of facial loculi de- scribed above, unlike the latter genus, the bothridia of Barbeaucestus possess, rather than lack, apical suckers, and unlike Escherbothrium and Stillabothrium, the new genus exhibits vitelline follicles that are conspicuously wider than long (rather than irregular to round) in shape and that encroach on the midline of the proglottid (rather than are limited to the lateral margins) of the proglottid.

The genus is fully consistent with the diagnosis of Anthocephaliidae presented by Ruhnke et al. (2015). The molecular phylogenetic analyses of Healy et al. (2009), Caira et al. (2014), Ruhnke et al. (2015) and Marques and Caira (2016) strongly support this familial placement for Barbeaucestus (as New genus 2).

Barbeaucestus jockuschae sp. $\mathrm{n}$.

Figs. 1, 2, 10B

ZooBank number for species:

urn:lsid:zoobank.org:act:434499D2-01E6-4771-99F6-89A33B7D299B

Informal synonym: New Genus 2 shipleyi of Healy et al. (2009), Caira et al. (2014), Ruhnke et al. (2015) and Marques and Caira (2016)

Description (based on eight whole mounts of mature specimens and one scolex prepared for SEM). Worms craspedote, euapolytic, $5.4-9.7 \mathrm{~mm}(7.0 \mathrm{~mm} \pm 1.6 \mathrm{~mm}$; $\mathrm{n}=8)$ long, with $103-123(115 \pm 8 ; \mathrm{n}=8)$ proglottids; maximum width $933-1,365(1,156 \pm 133 ; \mathrm{n}=8)$ at level of scolex. Scolex with 4 bothridia and cephalic peduncle; myzorhynchus absent. Bothridia stalked, wider than long, $703-1,029(881 \pm 116 ; \mathrm{n}=7)$ wide, with apical sucker and 3 rows of facial loculi folded along horizontal midline; bothridial margins with thin velum. Stalks 186-239 (216 \pm 27 ; $\mathrm{n}=3)$ long by $103-128(119 \pm 14 ; \mathrm{n}=3)$ wide. Apical sucker $68-85(76 \pm 6 ; \mathrm{n}=5)$ long by $82-113(97 \pm 12 ; \mathrm{n}$ $=6)$ wide. Facial loculus formula (6)(10)(14-16); loculi of central row conspicuously longer than loculi of anterior and posterior rows. Cephalic peduncle 86-108 (97 \pm 11 ; $\mathrm{n}=3$ ) long.

Distal surfaces of apical sucker and loculi (Fig. 2D), and septa (Fig. 2E) bearing small, gladiate spinitriches and capilliform filitriches; bothridial velum bearing capilliform filitriches throughout outermost edge with submarginal band of acicular filitriches on distal surface (Fig. 2C). Proximal surfaces of loculi of central row bearing densely arranged gladiate spinitriches and capilliform filitriches (Fig. 2F); proximal surfaces of loculi of posterior-most row and stalks bearing less densely arranged small gladiate spinitriches and acicular filitriches (Fig. 2G). Cephalic peduncle and strobila bearing capilliform filitriches.

Immature proglottids $102-121(113 \pm 7 ; \mathrm{n}=8)$ in number, wider than long. Mature proglottids $1-3(2 \pm 1 ; n=8)$ in number, longer than wide; terminal mature proglottid $718-1,246(950 \pm 172 ; \mathrm{n}=8)$ long by $416-537(468 \pm 39$; $\mathrm{n}=8)$ wide, length to width ratio 1.6-2.3 $(2.0 \pm 0.3 ; \mathrm{n}=8)$. Gravid proglottids not observed. Testes 20-26 (23 \pm 3 ; $\mathrm{n}=6)$ in number, $56-110(79 \pm 23 ; \mathrm{n}=6)$ long by $29-41$ $(n=6)$ wide, arranged in 2-4 irregular columns, anterior to cirrus sac, medullary. Vas deferens extending anteriorly 


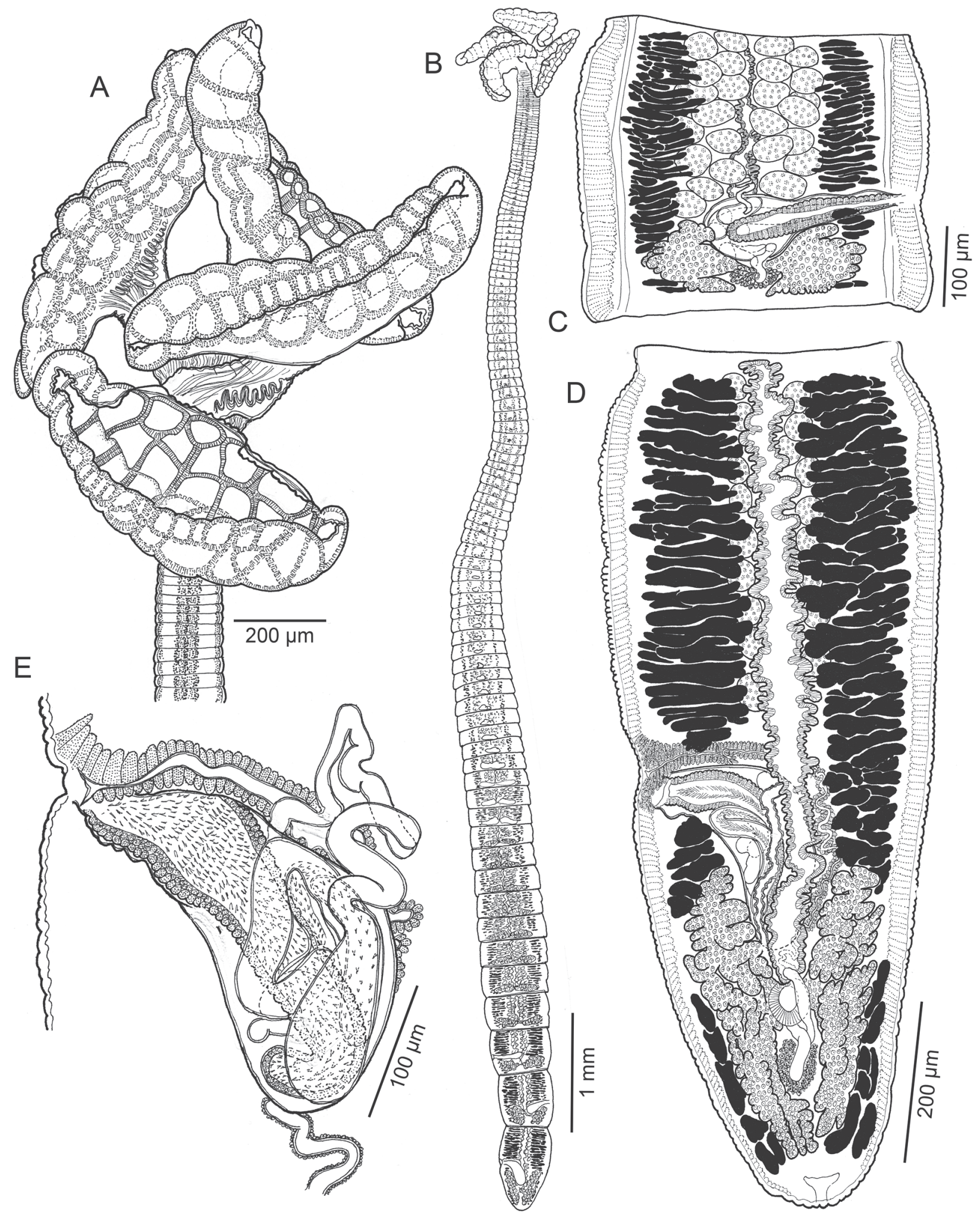

Fig. 1. Line drawings of Barbeaucestus jockuschae sp. n. from Neotrygon orientale Last, White et Séret. A - scolex (holotype, MZUM(P) 2016.18 (H)); B - whole worm (LRP 9160); C - subterminal mature proglottid (USNM 1422079); D - terminal mature proglottid (holotype, MZUM(P) 2016.18 (H)); E - detail of terminal genitalia (USNM 1422079).

from level of ovarian isthmus to enter cirrus sac at anterior margin, not expanded to form external seminal vesicle. Genital pore lateral, irregularly alternating, 45-54\% $(50 \% \pm 3 \% ; \mathrm{n}=8)$ from posterior end of proglottid; genital atrium shallow. Cirrus sac thin-walled, slightly bent and tilted posteriorly, 224-310 (270 $\pm 31 ; \mathrm{n}=5)$ long by 97-112 (105 $\pm 7 ; \mathrm{n}=5)$ wide, containing coiled cirrus; cirrus spinitriches present.

Vagina sinuous, extending along midline of proglottid from ootype region to anterior margin of cirrus sac, then 

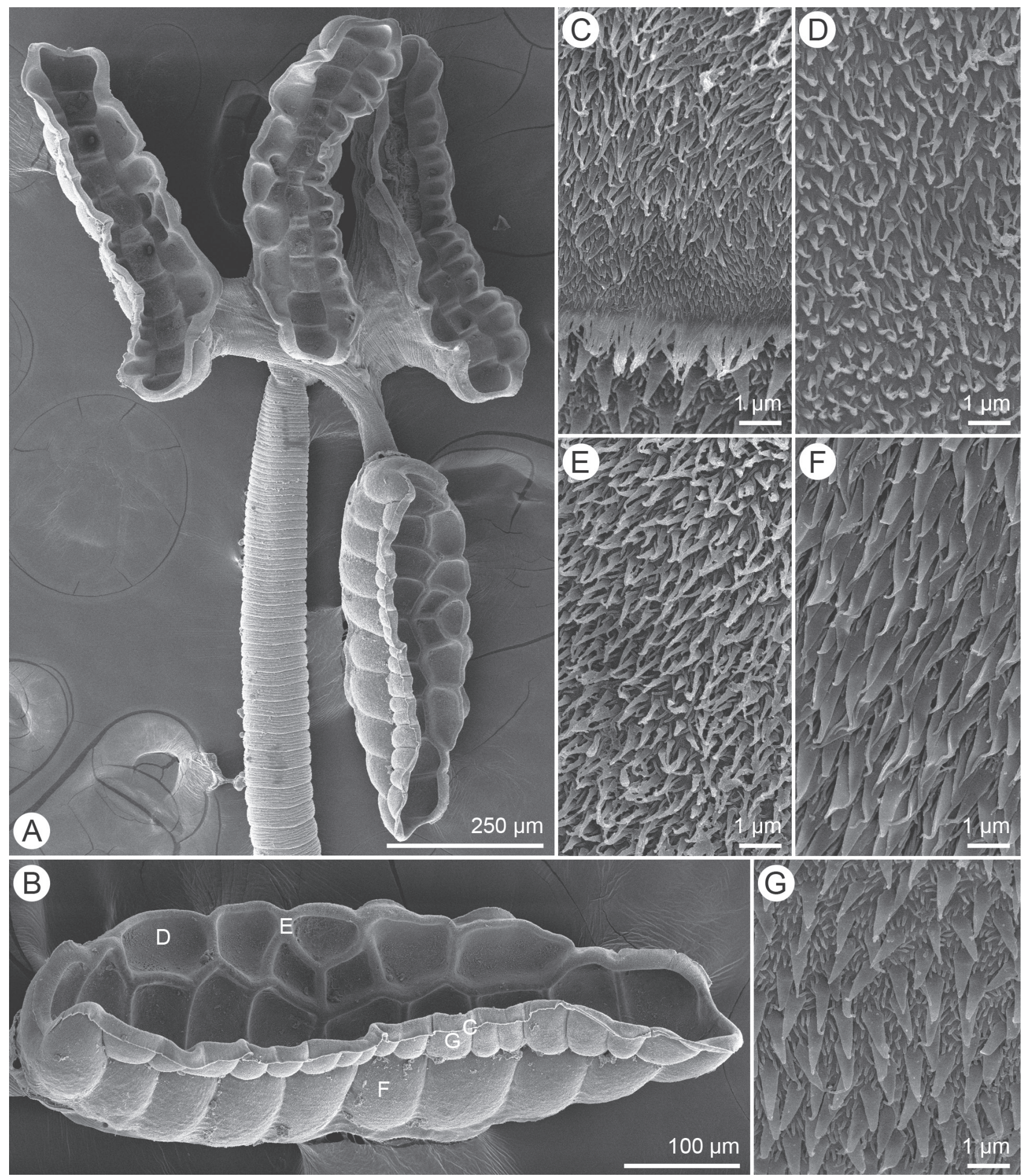

Fig. 2. Scanning electron micrographs of Barbeaucestus jockuschae sp. n. from Neotrygon orientale Last, White et Séret. A - scolex; B - bothridium; small letters indicate location of details shown in Fig. $2 \mathrm{C}-\mathrm{G}$; $\mathbf{C}$ - distal surface of bothridial velum; D - distal surface of loculus; $\mathbf{E}$ - distal surface of septum; $\mathbf{F}$ - proximal surface of loculus in central row; $\mathbf{G}$ - proximal surface of loculus in posterior-most row.

laterally to open into genital atrium anterior to cirrus sac; vaginal sphincter absent; seminal receptacle not observed. Ovary H-shaped in frontal view, 158-336 (223 $\pm 52 ; \mathrm{n}=8)$ long by $219-297(255 \pm 29 ; n=8)$ wide at isthmus, tetralobed in cross section; ovarian margins lobulate. Vitellarium follicular; follicles distinctly wider than long, in 2 lateral bands; each band consisting of 2-4 irregular columns of follicles, extending length of proglottid, interrupted by terminal genitalia and partially by ovary. Uterus median, ventral, weakly digitiform, extending from ovarian isthmus to anterior margin of proglottid; uterine duct joining uterus at posterior margin. Excretory vessels 4, arranged in 1 dorsal and 1 ventral pair on each lateral margin of proglottid. Eggs not observed. 
Type host: Neotrygon orientale Last, White et Séret (Neotrygon kuhlii 1 of Naylor et al. 2012), oriental bluespotted maskray (Dasyatidae: Myliobatiformes).

Site of infection: Spiral intestine.

Type locality: South China Sea, off Kuching $\left(02^{\circ} 30^{\prime} 07^{\prime \prime N}\right.$; $110^{\circ} 40^{\prime} 17^{\prime \prime E}$ ), Sarawak, Malaysian Borneo (BO-336).

Additional localities: South China off Pulau Balambangan (07¹6'29"N; 116 56'25"E), Sabah, Malaysian Borneo (BO-321).

Specimens examined: Holotype (MZUM(P) 2016.18 (H)) and 1 paratype (MZUM(P) $2016.19(\mathrm{P})$ ); 1 paratype (IPCAS C-746); 1 paratype (SBC-P-00074); 2 paratypes (USNM 1422078-1422079); 2 paratypes (LRP 9154, 9160). Scolex examined with SEM was retained with JNC at the University of Connecticut.

Ety mology: This species is named after Elizabeth Jockusch in appreciation of her enthusiastic willingness to expand her considerable molecular expertise to include the study of tapeworms and their elasmobranch hosts.

\section{Barbeaucestus ralickiae sp. $\mathrm{n}$.}

Figs. 3, 4, 10C

ZooBank number for species:

urn:lsid:zoobank.org:act:6333C75A-C061-4067-88E2-4FE68E7E36BD

Informal synonyms: New genus $2 \mathrm{cf}$. sexorchidum of Healy et al. (2009), Caira et al. (2014) and Marques and Caira (2016), and New genus 2 sexorchidum of Ruhnke et al. (2015)

Description (based on 11 whole mounts of mature specimens, six whole mounts of immature specimens of which one is incomplete and two scoleces prepared for SEM). Worms craspedote, euapolytic, $8.0-11.4 \mathrm{~mm}$ $(10.2 \mathrm{~mm} \pm 1.0 \mathrm{~mm} ; \mathrm{n}=11)$ long, with $102-163(127 \pm 19$; $\mathrm{n}=11)$ proglottids; maximum width $571-1,652(1,022 \pm$ $324 ; \mathrm{n}=9)$ at level of scolex. Scolex with 4 bothridia and cephalic peduncle; myzorhynchus absent. Bothridia stalked, wider than long, 337-761 (662 $\pm 75 ; \mathrm{n}=15)$ wide, with apical sucker and 5 rows of facial loculi, folded along horizontal centre line; bothridial margins with thin velum. Stalks $174-691(357 \pm 129 ; \mathrm{n}=13)$ long by $112-176(146 \pm 18 ; \mathrm{n}=13)$ wide. Apical sucker 48-67 $(56 \pm 7 ; \mathrm{n}=10)$ long by $65-88(77 \pm 6 ; \mathrm{n}=14)$ wide. Facial loculus formula (1)(4/6/6)(4); loculi of central row longer than loculi of anterior or posterior rows. Cephalic peduncle $117-202(141 \pm 41 ; n=4)$ long.

Distal surface of apical sucker, loculi (Fig. 4E) and septa bearing small, gladiate spinitriches and capilliform filitriches; bothridial velum bearing capilliform filitriches throughout outer-most edge (Fig. 4D) with submarginal band of acicular filitriches on distal surface. Proximal surfaces of loculi in anterior-most (Fig. 4F) and posterior-most (Fig. 4G) rows, and stalks (Fig. 4H) bearing densely arranged gladiate spinitriches and capilliform filitriches. Proximal surface of velum with complex arrangement of bands of microtriches (Fig. 4C). Cephalic peduncle and strobila bearing capilliform filitriches.
Immature proglottids $101-160(125 \pm 19 ; \mathrm{n}=11)$ in number, wider than long. Mature proglottids 1-3 $(1.8 \pm 0.8 ; \mathrm{n}=11)$ in number, longer than wide; terminal mature proglottid $725-952(805 \pm 70 ; n=9)$ long by $371-571(458 \pm 65 ; \mathrm{n}=9)$ wide, length to width ratio $1.4-2.5(1.8 \pm 0.4 ; \mathrm{n}=9)$. Gravid proglottids not observed. Testes 27-42 (32 $\pm 3 ; \mathrm{n}=13)$ in number, $36-57(47 \pm 6$; $\mathrm{n}=8)$ long by $22-33(28 \pm 3 ; \mathrm{n}=8)$ wide, arranged in 2-4 irregular columns, anterior to cirrus sac, medullary. Vas deferens extending anteriorly from level of ovarian isthmus to enter cirrus sac at anterior margin, not expanded to form external seminal vesicle. Genital pore lateral, irregularly alternating, $52-67 \%(60 \% \pm 5 \% ; \mathrm{n}=9)$ from posterior end of proglottid; genital atrium shallow. Cirrus sac thin-walled, bent and tilted posteriorly, 163-193 (180 \pm $10 ; \mathrm{n}=9)$ long by $83-103(91 \pm 9 ; \mathrm{n}=9)$ wide, containing coiled cirrus; cirrus spinitriches present.

Vagina sinuous, extending along midline of proglottid from ootype region to anterior margin of cirrus sac, then laterally to open into genital atrium anterior to cirrus sac; vaginal sphincter absent; seminal receptacle not observed. Ovary H-shaped in frontal view, 174-343 $(250 \pm 48 ; \mathrm{n}=8)$ long by $135-288(184 \pm 49 ; \mathrm{n}=8)$ wide at isthmus, tetralobed in cross section; ovarian margins lobulate. Vitellarium follicular; follicles distinctly wider than long, in 2 lateral bands; each band consisting of 2-3 irregular columns of follicles, extending length of proglottid, interrupted by terminal genitalia. Uterus median, ventral, sacciform, extending from ovarian isthmus to anterior margin of proglottid. Excretory vessels 4, arranged in 1 dorsal and 1 ventral pair on each lateral margin of proglottid. Eggs not observed.

Type host: Taeniura lymma 1 of Naylor et al. (2012) (Dasyatidae: Myliobatiformes).

Site of infection: Spiral intestine.

Type 1 ocality: Celebes Sea, off Semporna (042 $8^{\prime} 44^{\prime \prime N}$; $\left.118^{\circ} 37^{\prime} 01 " E\right)$ Sabah, Malaysian Borneo (BO-86).

Additional localities: Celebes Sea, off Kunak $\left(04^{\circ} 41^{\prime} 20^{\prime \prime N}\right.$; $\left.118^{\circ} 15^{\prime} 23^{\prime \prime E}\right)$, Sabah, Malaysia (BO-80); Pulau Mabul (0414'44"N; 118 37'53"E), Sabah, Malaysian Borneo (BO-123, BO-128, BO-130); Sulawesi Sea, off Pulau Rabu Rabu $\left(02^{\circ} 19^{\prime} 05^{\prime \prime N}\right.$; $\left.118^{\circ} 07^{\prime} 25^{\prime \prime E}\right)$, East Kalimantan, Indonesian Borneo (KA-419).

Specimens examined: Holotype (MZBCa 202) and 3 paratypes (MZBCa 203-205); 1 paratype (IPCAS C-747); 2 paratypes (MZUM(P) 2016.20 (P), MZUM(P) 2016.21 (P)); 5 paratypes (USNM 1422080-1422084); 5 paratypes (LRP 9150-9153, 9161). Scoleces examined with SEM were retained with JNC at the University of Connecticut.

Etymology: This species honours Hannah Ralicki for her herculean efforts to generate and expand the molecular data available for cestodes and their elasmobranch hosts.

Remarks. The arrangement of facial loculi in five, rather than three, rows readily distinguishes Barbeaucestus ralickiae sp. n. from $B$. jockuschae. In addition, the bothridia of $B$. ralickiae bear fewer loculi in the central row than do those of B. jockuschae (i.e. 6 vs 10). As a consequence, the bothridia of $B$. ralickiae are generally conspicuous- 


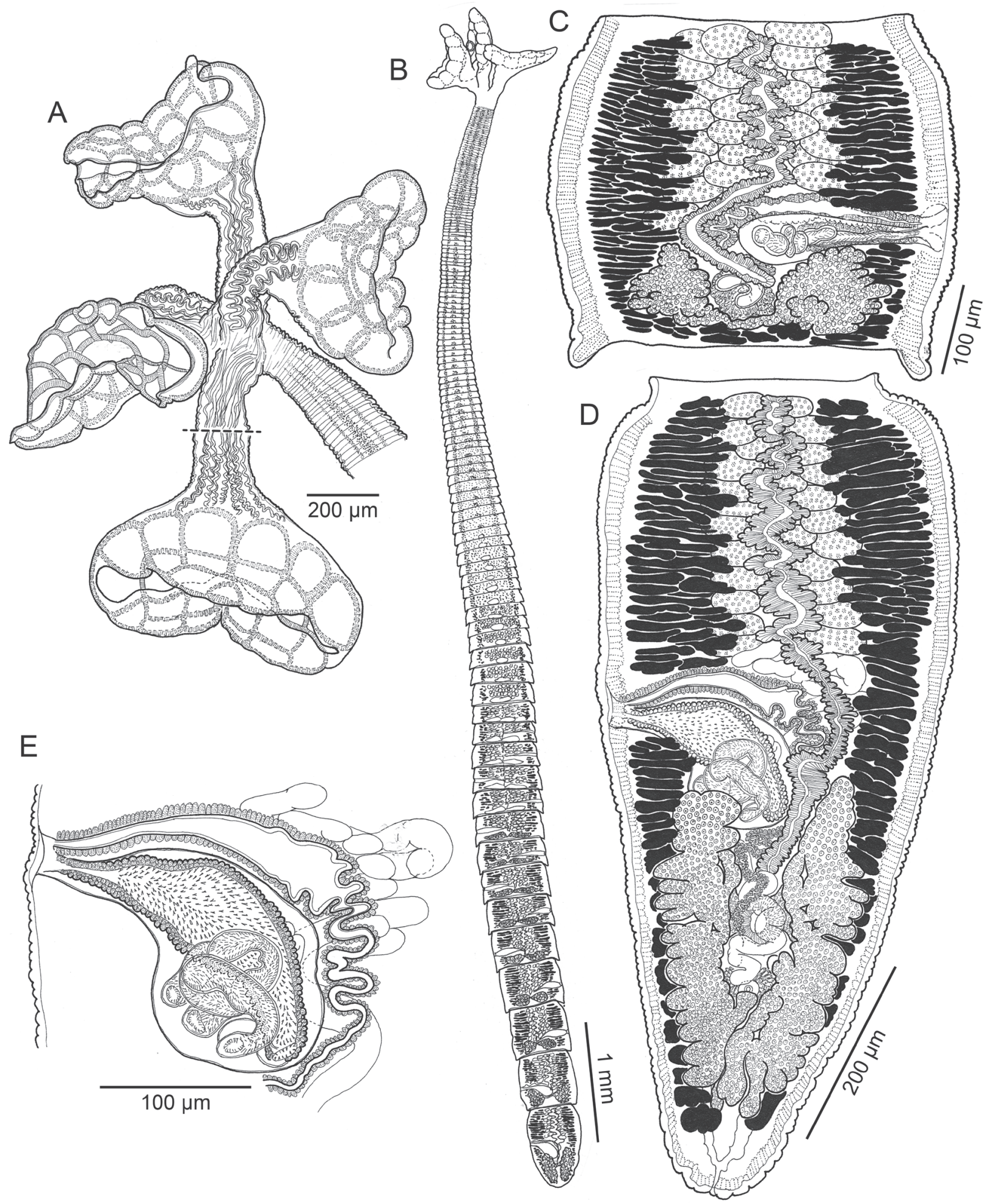

Fig. 3. Line drawings of Barbeaucestus ralickiae sp. n. from Taeniura lymma 1 of Naylor et al. (2012). A - scolex (holotype, MZBCa 202); B - whole worm (paratype, USNM 1422081); dashed line indicates that bothridium was cut and mounted separately; C - mature proglottid (paratype, LRP 9150); D - terminal mature proglottid (paratype, LRP 9150); E - detail of terminal genitalia (paratype, LRP 9150).

ly narrower than those of $B$. jockuschae (337-761 $\mu \mathrm{m} v \mathrm{~s}$ 703-1,029 $\mu \mathrm{m}$; Fig. 10C vs Fig. 10B). Finally, B. ralickiae possesses a greater number of testes (27-42 vs 20-26) and a shorter cirrus sac (163-193 $\mu \mathrm{m} v s$ 224-310 $\mu \mathrm{m})$ than B. jockuschae.
Barbeaucestus sexorchidus (Williams, 1964) comb. n.

Synonym: Anthobothrium sexorchidum Williams, 1964

Type host: Taeniura lymma 2 sensu Naylor et al. (2012) (as Taeniura lymma [Forsskål]), bluespotted ribbontail ray 

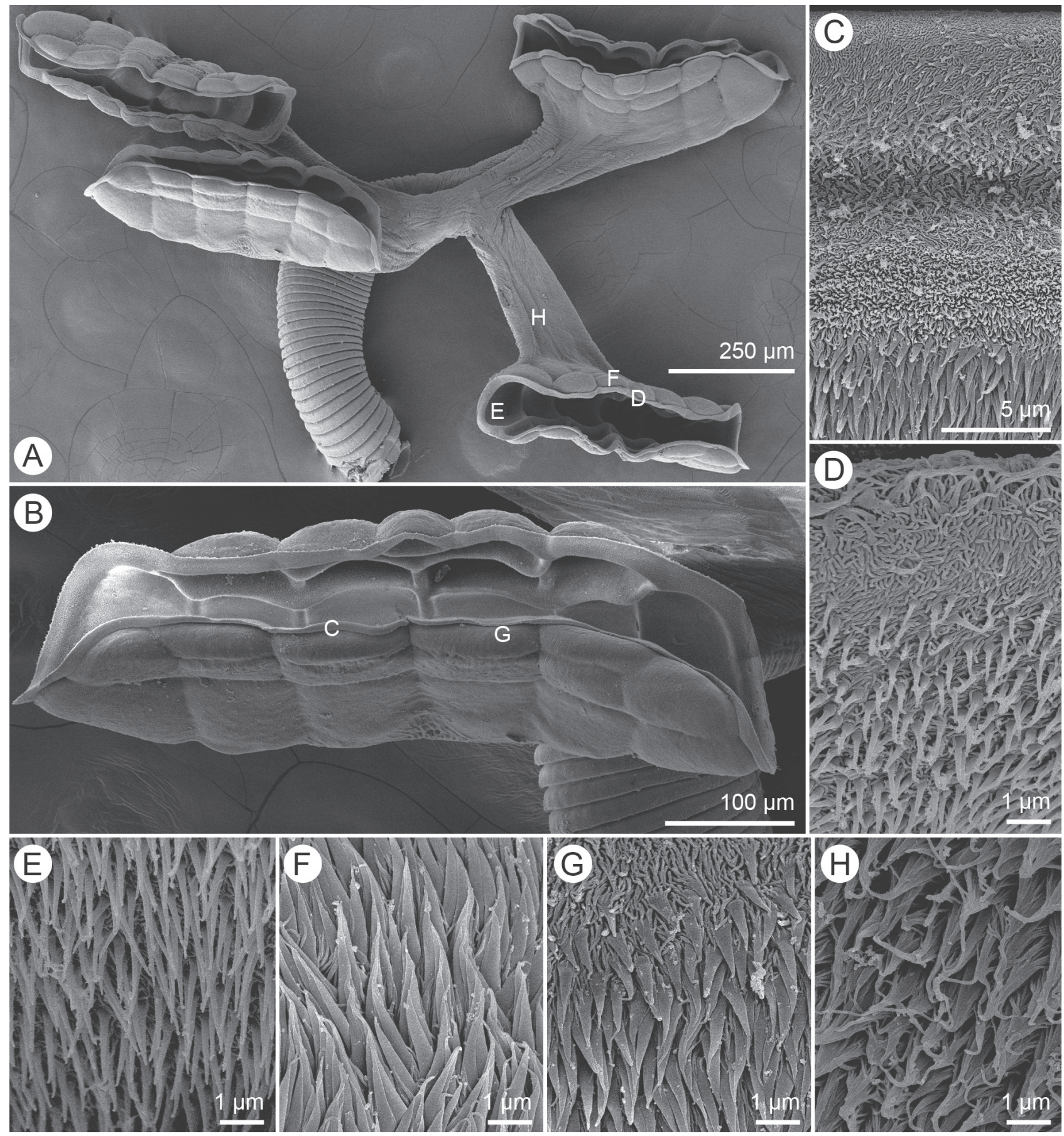

Fig. 4. Scanning electron micrographs of Barbeaucestus ralickiae sp. n. from Taeniura lymma 1 of Naylor et al. (2012). A - scolex; small letters indicate location of details shown in Fig. 4D-F,H; $\mathbf{B}$ - bothridium; small letters indicate location of details shown in Fig. 4C,G; C - proximal surface of bothridial velum; D - distal surface of bothridial velum; $\mathbf{E}$ - distal surface of loculus in central row; $\mathbf{F}$ - proximal surface of loculus in anterior-most row; $\mathbf{G}$ - proximal surface of loculus in posterior-most row; $\mathbf{H}$ - surface of stalk.

(Dasyatidae: Myliobatiformes).

Site of infection: Spiral intestine.

Type 1 o c a lity: Heron Island (232 $27^{\prime} S$; $\left.151^{\circ} 55^{\prime} \mathrm{E}\right)$, off Rockhampton, Queensland, Australia.

Specimens examined: SAM V1061 AHC 41061 (holotype).

Remarks. The type material of this species consists of two strobilae and four scoleces collected from 'Taeniura lymma' off Heron Island, Australia. Although Williams (1964) considered this material unsuitable for the gen- eration of a detailed description, he drew attention to its remarkable locular configuration by providing a brief diagnosis and drawings of a scolex, individual bothridium and mature proglottid. At that time, he assigned this species to Anthobothrium van Beneden, 1850 but was clear to state (Williams 1964, p. 743) "eventually, the placing of $A$. sexorchidum in another genus may be considered advisable." Indeed, examination of the holotype revealed this species to be fully consistent with Barbeaucestus and it is herein transferred to that genus as Barbeaucestus 
sexorchidus (Williams, 1964) comb. n. Examination of the holotype also leads us to believe that Williams (1964) may have slightly misinterpreted the features of the bothridia of this species. The bothridia bear (rather than lack) apical suckers, they are wider than long (rather than longer than wide) and bear three rows of loculi (rather than a single central row surrounded by marginal loculi). Unfortunately, the condition of the type material makes the number of rows and number of loculi per row difficult to assess with confidence and thus we have refrained from formally redescribing this species until additional material is available. There is also concern that the strobilae on which the original description was based differ substantially in proglottid morphology (Williams 1964; fig. 17) from that of the two species of the genus described here. This concern too would be addressed by examination of additional complete specimens from the type host and locality.

Nonetheless, as described by Williams (1964), Barbeaucestus sexorchidus is easily distinguished from both $B$. jockuschae and $B$. ralickiae in its possession of fewer number of testes ( 6 vs 20-26 and 27-42, respectively). It further differs from $B$. ralickiae in its possession of only three, rather than five, rows of loculi per bothridium. It further differs from $B$. jockuschae in its possession of what appears to be a maximum of six (rather than 10) loculi in its central row. Examination of additional, ideally more relaxed, material of $B$. sexorchidus would help to confirm these differences.

Much has changed with respect to the identity of specimens of Taeniura lymma since Williams conducted his work in 1964. Perhaps most importantly, this nominal taxon is now known to represent a complex of species each of which is somewhat regionally distributed; one of them was formally described as Taeniura lessoni Last, White et Naylor, just last year (Last et al. 2016c). Distinct from T. lessoni, Australian members of the T. lymma complex were considered distinct from those from Borneo by Naylor et al. (2012b) (referred to as Taeniura lymma 2 and T. lymma 1 , respectively). In contrast, despite documented sequence divergence in NADH2, Last et al. (2016b; see fig. 2) considered specimens of T. lymma from Australia and Borneo to be conspecific. In the absence of data to support conspecificity, "T. lymma" from Borneo and Australia are considered distinct; but we would note that neither is likely the real T. lymma originally described from the Red Sea. Thus, while B. ralickiae is hosted by Taeniura lymma 1 of Naylor et al. (2012), B. sexorchidus is hosted by the Australian Taeniura lymma 2 of Naylor et al. (2012).

Barbeaucestus shipleyi (Southwell, 1912) comb. n.

Fig. 5A

Synonyms: Rhinebothrium shipleyi Southwell, 1912; Echeneibothrium shipleyi (Southwell, 1912) Southwell, 1925; Scalithrium shipleyi (Southwell, 1912) Ball, Neifar et Euzet, 2003

Type host: Neotrygon kuhlii (Müller et Henle) (as Trygon kuhlii Müller et Henle), bluespotted stingray (Dasyatidae,
Myliobatiformes); Clade 8 of Puckeridge et al. (2013); Clade I of Borsa et al. (2016).

Site of infection: Spiral intestine.

Type locality: Sri Lanka (as Ceylon).

Specimens examined: BMNH No. 1977.11.1.9094 (3 slides with a total of 10 worms) and BMNH No. 1977.11.1.116-121 (4 slides with a total of 9 worms).

Remarks. The identity and generic placement of this taxon has been problematic since its provisional assignment to Rhinebothrium by Southwell (1912), who even then noted it might ultimately need to be transferred to a new genus. Among its unusual features, Southwell (1912; p. 267) considered the bothridia to be "compressed on a plane at right angles to the axis of the worm each being divided by transverse septa only into ten unpaired areolas." Despite lacking a myzorhynchus, the species was implicitly transferred to Echeneibothrium by Southwell (1925) when he synonymised it with Echeneibothrium minimum van Beneden, 1850. Although Yamaguti (1934) endorsed this generic placement, he considered E. shipleyi (Southwell, 1912) as valid. However, it should be noted that his treatment of this species was based on material collected from hosts identified as Dasyatis akajei (Müller et Henle) (now Hemitrygon akajei [Müller et Henle]) from Japan. Although the whereabouts of Southwell's type specimens of $R$. shipleyi were unknown, in 1958, Williams published the results of his investigations of voucher material - at the Liverpool School of Tropical Medicine - collected by Southwell in 1923 from hosts identified as 'Trygon kuhli' (now Neotrygon kuhlii) in Sri Lanka. Although Williams initially considered this material to include specimens of Rhinebothrium trygonis (Shipley et Hornell, 1906) - a species described from hosts identified as 'Trygon walga' (now Brevitrygon walga [Müller et Henle]) by Shipley and Hornell 1906 - he ultimately attributed the variation among specimens to differences in development and/or degree of contraction, and treated all of the material as $R$. trygonis, considering $R$. shipley $i$ as a junior synonym. Most recently, Ball et al. (2003) transferred $R$. shipleyi to their new genus Scalithrium on the basis of its possession of multiple transverse, but no longitudinal, septa. These authors also provided a revised description based on a combination of data from Southwell (1912) and Williams (1958).

In the absence of type material, Southwell's voucher specimens collected from the type host in the type locality, and examined by Williams (1958), now housed at the $\mathrm{BMNH}$, currently provide the best insight into the identity of $R$. shipleyi. However, our examination of these specimens leads us to conclusions that differ from those reached by Williams. First, we are unconvinced that $R$. shipleyi is a synonym of $R$. trygonis. Whereas Southwell (1912) described the former as a robust worm that reaches a length of $60 \mathrm{~mm}$ and bears bothridia with 10 areolae (i.e. loculi), Shipley and Hornell (1906) described the latter as a delicate worm of up to $15 \mathrm{~mm}$ in length, bearing bothridia with only seven or eight areolae. Second, we do not believe any of these BMNH specimens are of R. trygonis. In addition to differing from that species in size and overall morphol- 

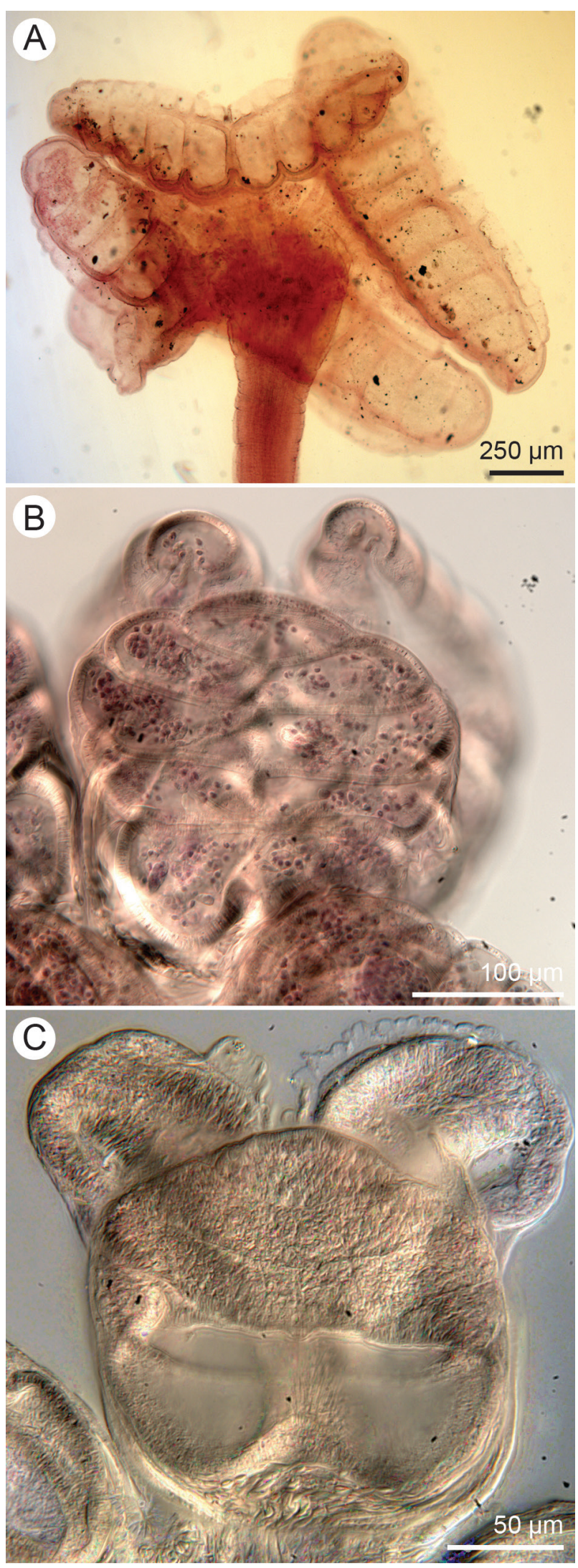

Fig. 5. Light micrographs of scoleces. A - scolex of Barbeaucestus shipleyi (Southwell, 1912) comb. n. from Neotrygon kuhlii (Müller et Henle) (neotype, BMNH 1977.11.1.116-121A); B - bothridium of undescribed species of Divaricobothrium from Pateobatis jenkinsii (BO-339) (voucher, LRP 9158); C - bothridium of undescribed species of Divaricobothrium from Maculabatis cf. pastinacoides (BO-61) (voucher, LRP 9159). ogy, these specimens were also collected from Neotrygon kuhlii rather than the type host of $R$. trygonis, Brevitrygon walga. We agree with Williams' original inclination that the BMNH material includes two different forms. The larger 13 of these 19 specimens are consistent with Southwell's original (1912) description of $R$. shipleyi and we have designated one of these (BMNH No. 1977.11.1.116-121A) as a neotype (Fig. 5A). This species is formally transferred here to Barbeaucestus for the reasons outlined below. We do not, however, believe the smaller specimens among this material are conspecific with $R$. trygonis, rather they appear to represent a second undescribed species of Barbeaucestus that also parasitises specimens of the Neotrygon kuhlii complex in Sri Lanka. In addition to being longer than $R$. trygonis (16.5-24.1 mm vs $15 \mathrm{~mm}$ ) in total length, they bear 10-11 (rather than 7-8) loculi in the central row on each bothridium, which was likely the only row seen by Shipley and Hornell (1906). Moreover, unlike the illustration provided in the original description, the strobila of these specimens is much wider posteriorly than anteriorly (rather than vice versa).

Our examination of this material led us to realise that Southwell (1912), Williams (1958) and Ball et al. (2003) had misinterpreted the unique nature of the bothridial morphology of this species, which fueled the confusion surrounding its generic placement. In all three cases, the authors concentrated on the central row of largest loculi. While, the first two authors recognised the presence of additional bothridial tissue flanking this central row, none of these authors recognised that the bothridia bore additional rows of loculi. Furthermore, in all three works, the orientation of the bothridia was misinterpreted such that what actually constitute the anterior and posterior edges of the bothridia were considered to represent the lateral edges. We believe these misinterpretations led to the assumption of close affinities between this species and those of Echeneibothrium, Rhinebothrium and ultimately Scalithrium. It is now clear that the morphology of $R$. shipleyi is fully consistent with that of species of Barbeaucestus and it is hereby transferred to this genus, as B. shipleyi (Southwell, 1912) comb. n. Unfortunately, available material is insufficient to allow formal redescription of this species at this time. That task must await the collection of additional material from the type host in the type locality. We believe Yamaguti's (1934) material from Hemitrygon akajei (as Dasyatis akajei) likely represents yet an additional undescribed species. The remaining smaller specimens among Southwell's BMNH material (BMNH No. 1977.11.1.116-121B) likely represent an undescribed species of Barbeaucestus.

The presence of ten (Fig. 5A), rather than six, loculi in the central row of the bothridia of B. shipleyi easily distinguishes it from B. ralickiae. Barbeaucestus shipleyi differs conspicuously from B. jockuschae and B. sexorchidum in that it is a much larger worm (42-60 mm vs 5.4-9.7 mm and $10 \mathrm{~mm}$ in total length, respectively).

The identity of the type host of $B$. shipleyi remains in question. Recent molecular work on the species complex Neotrygon kuhlii by Puckridge et al. (2013) identified the form found in India, and thus likely also Sri Lanka, 


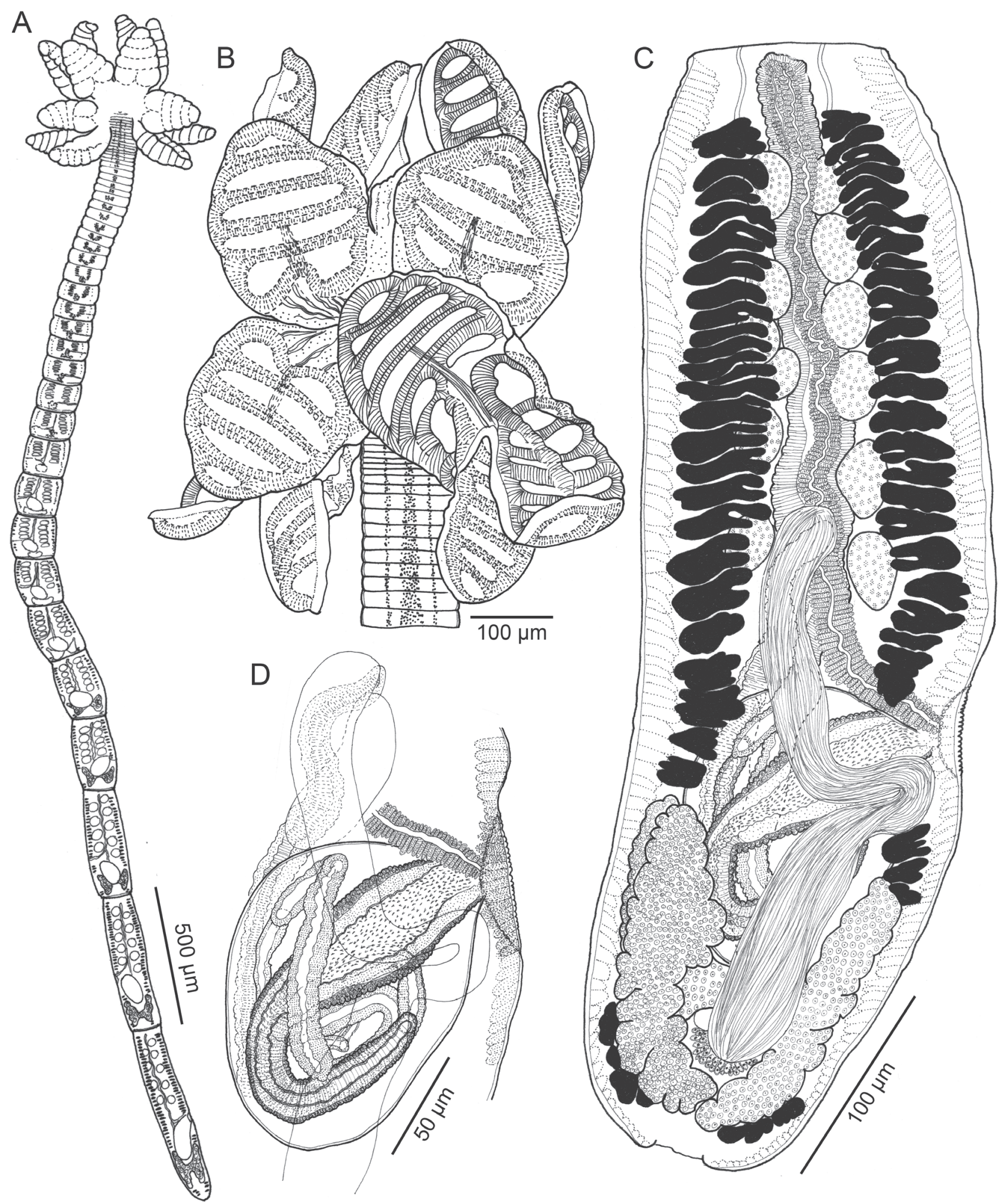

Fig. 6. Line drawings of Divaricobothrium tribelum sp. n. from Maculabatis gerrardi (Gray). A - whole worm (holotype; MZUM(P) 2016.16 (H)); B - scolex (paratype, USNM 1422077); C - terminal mature proglottid (paratype, LRP 9155); D - detail of terminal genitalia (paratype, LRP 9155).

as Clade 8. Despite recent revisionary work to align the taxonomy of this elasmobranch species complex with such molecular findings (e.g. Last et al. 2016a), a formal taxon name has yet to be proposed for the form in that region. 


\section{Divaricobothrium gen. n.}

ZooBank number for genus:

urn:1sid:zoobank.org:act:DC51AE93-DB6A-43A4-AD6B-B702136D43A8

Informal synonym: New genus 1 of Healy et al. (2009), Caira et al. (2014), Ruhnke et al. (2015) and Marques and Caira (2016)

Diagnosis. Rhinebothriidea: Anthocephaliidae. Worms craspedote, euapolytic. Scolex with 4 bothridia; cephalic peduncle and myzorhynchus absent. Bothridia stalked, longer than wide, with distinct anterior and posterior regions. Anterior bothridial region lacking apical sucker, with single apical loculus followed by multiple single and/ or multiple pairs of facial loculi. Posterior bothridial region medially divided into 2 lobes; each lobe with single column of multiple loculi. Mature proglottids longer than wide. Testes numerous, arranged in 2 columns anterior to cirrus sac. Vas deferens extending anteriorly from level of ovarian isthmus to well anterior of cirrus sac, recurving to enter cirrus sac at anterior margin, expanded to form external seminal vesicle. Genital pores lateral, irregularly alternating; genital atrium shallow. Cirrus sac thin-walled, tilted posteriorly, containing coiled cirrus; cirrus armed with spinitriches. Vagina weakly sinuous, extending from ootype along midline of proglottid to anterior margin of proglottid, recurving posteriorly, then laterally to open into genital atrium anterior to cirrus sac; vaginal sphincter absent; seminal receptacle not observed. Ovary H-shaped in frontal view, tetralobed in cross section; ovarian margins weakly lobulate. Vitellarium follicular; follicles distinctly wider than long, in 2 lateral bands; each band consisting of 2 columns of follicles, extending length of proglottid, interrupted by terminal genitalia and partially by ovary. Uterus median, ventral, sacciform, extending from ovarian isthmus to anterior margin of proglottid. Excretory vessels 4 , arranged in 1 dorsal and 1 ventral pair on each lateral margin of proglottid. Parasites of Dasyatidae (Myliobatiformes), Indo-Pacific Ocean.

Type species: Divaricobothriurn tribelum gen. n. et sp. n.

Additional species: Divaricobothrium trifidum (Shipley et Hornell, 1906) comb. $n$.

E t y m o log y: From divarico (from Latin - spread apart, fork), in reference to the posteriorly forked configuration of the bothridia.

Remarks. The most diagnostic feature of Divaricobothrium gen. $\mathrm{n}$. is the posteriorly bifid nature of its bothridia. Among the valid rhinebothriidean genera (see Ruhnke et al. 2015 as modified by Marques and Caira 2016), this feature clearly distinguishes it from all but Cairaeanthus. It differs from Cairaeanthus in its lack (rather than possession) of marginal loculi and its possession (rather than lack) of facial loculi. In addition, species of Cairaeanthus bear extensive lateral fields of numerous, small vitelline follicles that extend almost to the midline of the proglottid, whereas the vitelline follicles of Divaricobothrium are large, much wider than long, and are arranged in two discrete bands, each consisting of only two columns of follicles.

Species of Divaricobothrium are also highly unusual among rhinebothriideans in their possession of an extremely long, recurved vagina. Among known rhinebothriideans, this feature is seen only in Rhinebothrium setiensis Euzet, 1955 (see Euzet 1955) and Rhabdotobothrium dollfusi Euzet, 1953 (see Euzet 1953). However, in both of the latter cases the vagina extends barely into the anterior quarter, rather than to the anterior margin, of the proglottid, as in species of Divaricobothrium.

In terms of its familial placement, Divaricobothrium is highly supported as a member of the Anthocephaliidae in trees resulting from all molecular phylogenetic analyses (Healy et al. 2009, Caira et al. 2014, Ruhnke et al. 2015, Marques and Caira 2016). Morphologically, it is consistent with the revised diagnosis of this family presented by Ruhnke et al. (2015) with one exception. The bothridia appear to lack, rather than possess, apical suckers. As a consequence, its inclusion in the Anthocephaliidae requires emendation of the family diagnosis to read "apical sucker present or absent." This revision also requires a slight modification of the key to rhinebothriidean families presented by Ruhnke et al. (2015): the second phrase in couplet 2 should be changed to read "with, or occasionally without, apical suckers."

In addition to the two species of Divaricobothrium treated here, preliminary examination of cestodes from stingrays in the waters of Borneo yielded two additional potentially new species - one from Pateobatis jenkinsii (Annandale) and one from a second species of Maculabatis, $M$. cf. pastinacoides (Bleeker). Unfortunately, in neither case was sufficient material available to allow formal description. The generic diagnosis presented here accommodates both of these species, one of which exhibits paired loculi throughout the entire length of the anterior region of the bothridium following the first loculus (Fig. 5B), and the other of which bears a combination of single and paired loculi in the anterior bothridial region (Figs. 5C, 10E). For future reference, one specimen from each host species has been deposited in the LRP (Nos. 9158 and 9159, respectively).

Divaricobothrium tribelum sp. n.

Figs. 6, 7, 10E

ZooBank number for species:

urn:1sid:zoobank.org:act:307F3CCB-9B35-4443-B230-4B907A50673D

Informal synonym: New genus $1 \mathrm{n}$. sp. of Healy et al. (2009), Caira et al. (2014), Ruhnke et al. (2015) and Marques and Caira (2016)

Description (based on eight whole mounts of mature specimens and two scoleces prepared for SEM). Worms craspedote, euapolytic, $4.2-7.3 \mathrm{~mm}(5.4 \mathrm{~mm} \pm 1.1 \mathrm{~mm}$; $\mathrm{n}=8) \mathrm{mm}$ long, with $32-53(40 \pm 9 ; \mathrm{n}=8)$ proglottids; maximum width $538-858(663 \pm 108 ; \mathrm{n}=8)$ at level of scolex. Scolex with 4 bothridia; cephalic peduncle and 

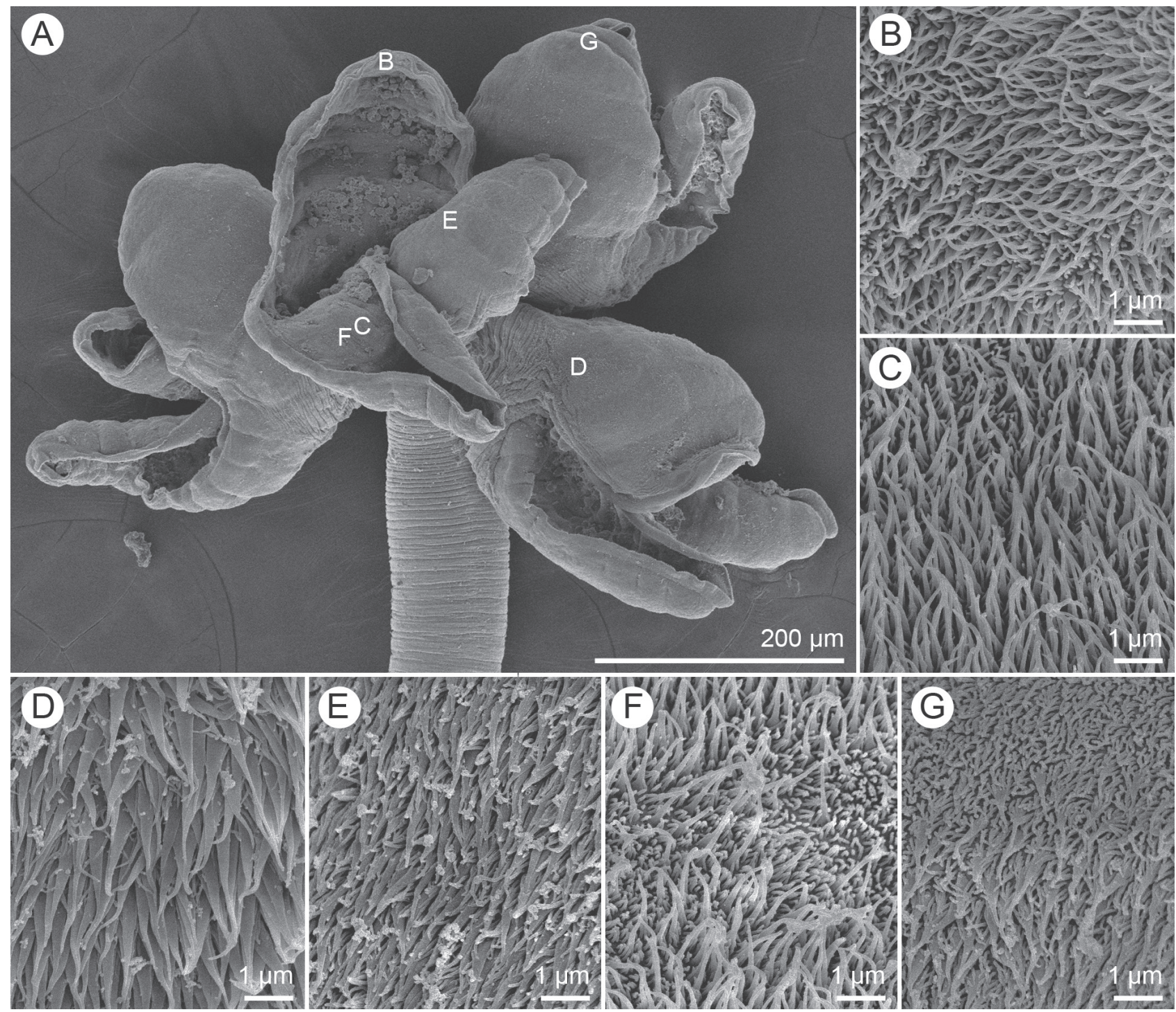

Fig. 7. Scanning electron micrographs of Divaricobothrium tribelum sp. n. from Maculabatis gerrardi (Gray). A - scolex; small letters indicate location of details shown in Fig. 7B-G; B - distal surface of anterior-most loculus in anterior bothridial region; $\mathbf{C}$ - distal surface of loculus in lobe of posterior bothridial region; D - proximal surface of loculus in anterior bothridial region; $\mathbf{E}$ - proximal surface of loculus in lobe of posterior bothridial region; F - distal surface of septum in lobe of posterior bothridial region; $\mathbf{G}$ - proximal surface of anterior loculus in anterior bothridial region.

myzorhynchus absent. Bothridia stalked, longer than wide, with distinct anterior and posterior regions; bothridial margins with thin velum; apical sucker absent. Anterior bothridial region $174-288(231 \pm 39 ; \mathrm{n}=7)$ long by $157-247$ $(191 \pm 29 ; n=7)$ wide, with 3 single loculi followed by 2 pairs of loculi. Posterior bothridial region medially divided into 2 lobes; each lobe 239-337 (292 \pm 37 ; $\mathrm{n}=6)$ long by $107-175(135 \pm 32 ; \mathrm{n}=5)$ wide, with single column of $8-9$ loculi.

Distal surfaces of loculi of anterior region (Fig. 7B) and posterior region (Fig. 7C) with densely arranged small gladiate spinitriches and acicular filitriches; distal surfaces of septa of posterior region (Fig. 7F) with sparse small gladiate spinitriches and acicular filitriches. Proximal surfaces of loculi in anterior region (Fig. 7D) with densely arranged gladiate spinitriches and capillifom filitriches, transitioning to acicular filitriches only near apex of both- ridium (Fig. 7G); proximal surfaces of loculi of posterior region (Fig. 7E) with densely arranged gladiate spinitriches and capilliform filitriches. Strobila with capilliform filitriches.

Immature proglottids $27-48(35 \pm 8 ; \mathrm{n}=8)$ in number, wider than long. Mature proglottids $3-7(5 \pm 1 ; n=8)$ in number, longer than wide; terminal mature proglottid 533-668 (607 $\pm 47 ; \mathrm{n}=8)$ long by $114-169(142 \pm 21$; $\mathrm{n}=8)$ wide, length to width ratio $3.2-5.7(4.4 \pm 0.8 ; \mathrm{n}=8)$. Gravid proglottids not observed. Testes 9-12 (10 \pm 1 ; $\mathrm{n}=7)$ in number, $32-44(37 \pm 5: \mathrm{n}=6)$ long by $25-30$ $(28 \pm 2 ; n=6)$ wide, arranged in 2 columns, anterior to cirrus sac, medullary. Vas deferens extending anteriorly from level of ovarian isthmus to well anterior of cirrus sac, recurving to enter cirrus sac at anterior margin, expanded to form external seminal vesicle. Genital pore lateral, irregularly alternating, $42-49 \%(45 \pm 3 ; \mathrm{n}=8)$ from posterior 
end of proglottid; tegument surrounding genital pore bearing small tubercles; genital atrium shallow. Cirrus sac thinwalled, bent posteriorly, $121-153(137 \pm 12 ; \mathrm{n}=7)$ long by 55-82 (71 $\pm 9 ; n=7)$ wide, containing coiled cirrus; cirrus spinitriches present.

Vagina extensive, weakly sinuous, extending along midline of proglottid from ootype region to anterior margin of proglottid, then recurving posteriorly to anterior margin of cirrus sac, then laterally to open into genital atrium anterior to cirrus sac; vaginal sphincter absent; seminal receptacle not observed. Ovary H-shaped in frontal view, 138-226 $(185 \pm 33 ; \mathrm{n}=8)$ long by $68-112(91 \pm 17 ; \mathrm{n}=8)$ wide, tetralobed in cross section; ovarian margins weakly lobulated. Vitellarium follicular; follicles distinctly wider than long, in 2 lateral bands; each band consisting of 2 columns of follicles, extending length of proglottid, interrupted by terminal genitalia and partially by ovary. Uterus median, ventral, sacciform, extending from ovarian isthmus to anterior margin of proglottid. Excretory vessels 4, arranged in 1 dorsal and 1 ventral pair on each lateral margin of proglottid. Eggs not observed.

Type host: Maculabatis gerrardi (Gray) (as Himantura cf. gerrardi 2 sensu Naylor et al. 2012) (Dasyatidae, Myliobatiformes).

Site of infection: Spiral intestine.

Type loc a lity: South China Sea, off Sematan $\left(01^{\circ} 48^{\prime} 15^{\prime \prime N}\right.$; $109^{\circ} 46^{\prime} 47^{\prime \prime E}$ ) Sarawak, Malaysian Borneo (BO-158; also locality for host BO-23).

Additional localities: Celebes Sea, off Tawau $\left(02^{\circ} 15^{\prime} 00^{\prime \prime N}\right.$; $\left.117^{\circ} 54^{\prime} 00^{\prime \prime E}\right)$, Sabah, Malaysian Borneo (BO88); South China Sea off Mukah (02 $53^{\prime} 52^{\prime \prime N}$; $\left.112^{\circ} 05^{\prime} 44^{\prime \prime E}\right)$, Sarawak, Malaysian Borneo (BO-466, host of hologenophore of Healy et al. 2009).

Specimens examined: Holotype (MZUM(P) 2016.16 (H)) and 1 paratype, (MZUM(P) $2016.17(\mathrm{P}))$; 1 paratype (IPCAS C-745); 1 paratype (SBC-P-00073); 2 paratypes (USNM 1422076-1422077); 3 paratypes (LRP 9155-9157; 2 whole worms and 1 SEM strobilar voucher). Scoleces examined with SEM were retained with JNC at the University of Connecticut.

E t y m o log y: This name, from the Greek tribelos (3-pointed), was chosen because of the shape of the bothridia of this species.

Divaricobothrium trifidum (Shipley et Hornell, 1906) comb. n.

Fig. 10D

\footnotetext{
1906 batiformes).

Site of injection: Spiral intestine.

Type locality: Sri Lanka (as Ceylon).

Specimens examined: None.
}

Synonym: Echeneibothrium trifidum Shipley et Hornell

Type host: Brevitrygon walga (Müller et Henle) (as Trygon walga Müller et Henle), dwarf whipray (Dasyatidae, Mylio-

Remarks. Shipley and Hornell (1906) originally described this species from three immature specimens collected from Brevitrygon walga (as Trygon walga) in Sri Lanka (as Ceylon). Unfortunately, the type material ap- pears to have been lost and the species is known only from the brief original description, lacking detail of proglottid anatomy. Nonetheless, Shipley and Hornell (1906) did capture the unique trifid configuration of the bothridia of the species and, apart from misinterpreting the anterior/ posterior orientation of the bothridia, provided a detailed description of that morphology (Shipley and Hornell 1906, p. 80): "The basal or posterior half of each bothridium is single, and carries nine transversely elongated areolas. The proximal end of each bothridium is, however, split into two halves, and each half bears nine areolas, of a somewhat rounded form." As in other rhinebothriideans, the stalked nature of the bothridia can lead to preparations in which the bothridia are mounted in a diversity of positions as seen in their fig. 99. Given this, the affinities of this species with Divaricobothrium are clear and it is hereby transferred to this genus as Divaricobothrium trifidum (Shipley et Hornell, 1906) comb. n.

Divaricobothrium trifidum is easily distinguished from D. tribelum in both the number and arrangement of the bothridial loculi. Whereas the former species has a column of nine loculi on the anterior bothridial region and a single column of nine loculi on each lobe of the posterior bothridial region (for a total of 27 loculi; see Fig. 10D), the latter species bears three single loculi followed by two pairs of loculi on the anterior bothridal region and a single column of eight loculi on each lobe of the posterior bothridial region (for a total of only 21 loculi; see Fig. 10E). Whether $D$. trifidum will be found to possess an extremely long, recurved vagina remains to be determined, but both of the undescribed species mentioned above also possess this feature, suggesting it may be a feature of the genus.

\section{Sungaicestus gen. n.}

ZooBank number for genus:

urn:1sid:zoobank.org:act:03623D8C-4CE2-4DFE-B491-7337EB5E3967

Informal synonym: New genus 4 of Healy et al. (2009), Caira et al. (2014), Ruhnke et al. (2015) and Marques and Caira (2016)

Diagnosis. Rhinebothriidea, Anthocephaliidae. Worms crapedote, euapolytic. Scolex with 4 bothridia; cephalic peduncle and myzorhynchus absent. Bothridia stalked, slightly longer than wide, with apical sucker and facial loculi; bothridial margins with thin velum. Loculi arranged in 2 columns, wider than long. Mature proglottids longer than wide. Testes numerous, arranged in 2 columns anterior to cirrus sac. Vas deferens extending anteriorly from level of ovarian isthmus to enter cirrus sac at anterior margin, expanded to form external seminal vesicle. Genital pores lateral, irregularly alternating; genital atrium shallow. Cirrus sac thin-walled, slightly bent posteriorly, containing coiled cirrus; cirrus armed with spinitriches. Vagina weakly sinuous, extending from ootype along midline of proglottid to anterior margin of cirrus sac, then laterally to open into genital atrium anterior to cirrus sac; vaginal sphincter absent; seminal receptacle not observed. Ovary H-shaped 
in frontal view, tetralobed in cross section; ovarian margins lobulate. Vitellarium follicular; follicles distinctly wider than long, in 2 lateral bands; each band consisting of 2 columns of follicles, extending length of proglottid, interrupted by terminal genitalia and partially by ovary. Uterus median, ventral, sacciform, extending from ovarian isthmus to anterior margin of proglottid. Excretory vessels 4 , arranged in 1 dorsal and 1 ventral pair on each lateral margin of proglottid. Parasites of Urogymnus (Dasyatidae, Myliobatiformes), Indo-Pacific Ocean.

Type species: Sungaicestus kinabatanganensis (Healy, 2006) comb. $n$.

Etymology: This name is a contraction of the Malay word for river, sungai, and the Latin word for worm, cestus, and refers to the fact that the type species of this genus was discovered in rays from the Kinabatangan River, Malaysian Borneo.

Remarks. The lack of a myzorhynchus easily distinguishes Sungaicestus gen. n. from Clydonobothrium, Echeneibothrium, Notomegarhynchus, Phormobothrium, Pseudanthobothrium and Tritaphros, all of which possess this feature in their adult forms. The lack of marginal loculi distinguishes this new genus from Anindobothrium, Anthocephalum and Cairaeanthus, all of which exhibit marginal loculi. Unlike those of Divaricobothrium, the bothridia of the new genus are not bifid posteriorly. Unlike Stillabothrium, Zyxibothrium and all eight genera of Rhinebothriidae (i.e. Biotobothrium, Crassuseptum, Rhinebothrium, Rhinebothroides, Rhodobothrium, Scalithrium, and Spongiobothrium), Sungaicestus possesses an apical sucker. Sungaicestus differs from Rhabdotobothrium in lacking post-vaginal testes. It differs conspicuously from Barbeaucestus and Escherbothrium in that, unlike these genera, it bears no more than two loculi in any row.

Sungaicestus kinabatanganensis (Healy, 2006) comb. $\mathrm{n}$

Figs. 8, 9, 10F

Synonyms: Rhinebothrium kinabatanganensis Healy, 2006; New genus 4 kinabatanganensis of Healy et al. (2009), Caira et al. (2014), Ruhnke et al. (2015) and Marques and Caira (2016)

Type host: Urogymnus polylepis (Müller et Henle) (as Himantura chaophraya Monkolprasit et Roberts in Healy 2006b), giant freshwater whipray (Dasyatidae, Myliobatiformes).

Site of infection: Spiral intestine.

Type Locality: Kinabatangan River, Kampung Abai (0541'11"N; 118 23'08"E), Sabah, Malaysian Borneo.

Specimens examined: MZUM(P) 155 (photographs of holotype), LRP 3738 (paratype), LRP 3739 (paratype SEM and SEM voucher); LRP 3900 (hologenophore voucher of CH-9 of Healy et al. [2009]); LRP 8907 (voucher, scolex drawn in Fig. 8).

Remarks. Rhinebothrium kinabatanganensis was described by Healy (2006b) based on six complete and one incomplete worm (i.e. the strobilar voucher of the specimen used for scanning electron microscopy). While otherwise

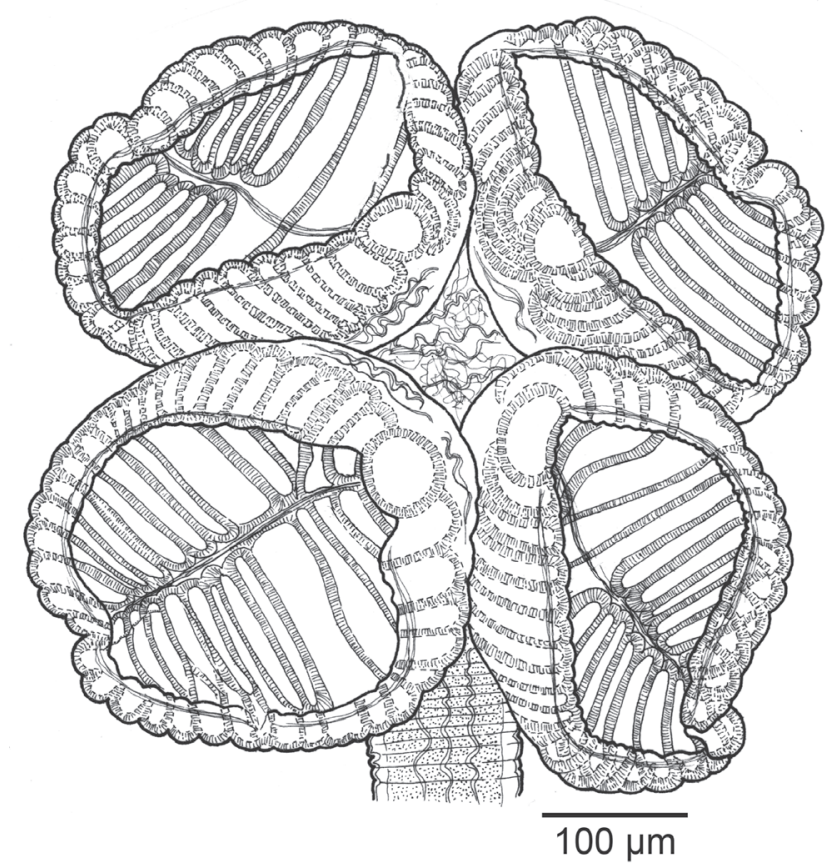

Fig. 8. Line drawing of the scolex of Sungaicestus kinabatanganensis (Healy, 2006) comb. n. from Urogymnus polylepis (Müller et Henle) (voucher, LRP 8907).

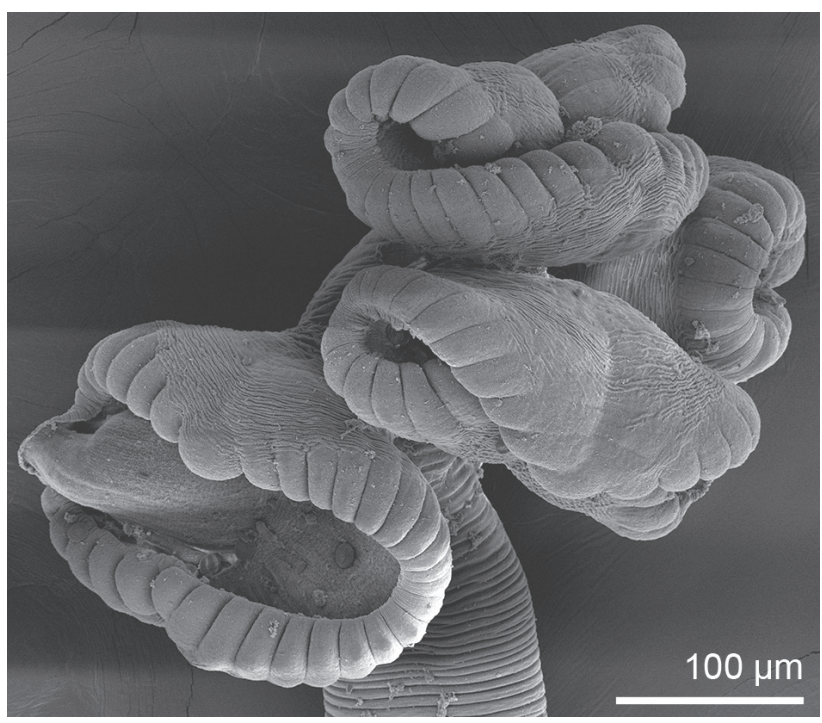

Fig. 9. Scanning electron micrograph of the scolex of Sungaicestus kinabatanganensis (Healy, 2006) comb. n. from Urogymnus polylepis (Müller et Henle). Retaken from Healy (2006b).

consistent with the generic diagnosis of Rhinebothrium (i.e. lacking a myzorhynchus and postvaginal testes, and possessing facially loculated bothridia with a single longitudinal septum), Healy (2006b) noted that $R$. kinebatanganensis was unique among the members of its genus in lacking vitelline follicles lateral to the ovary. In her subsequent dissertation, Healy (2006a) reported additional morphological and preliminary phylogenetic evidence supporting the erection of a new genus for this species. Thus, this species was referred to as "New genus 4 kinabatanganensis" in the molecular phylogenetic study that resulted in erec- 

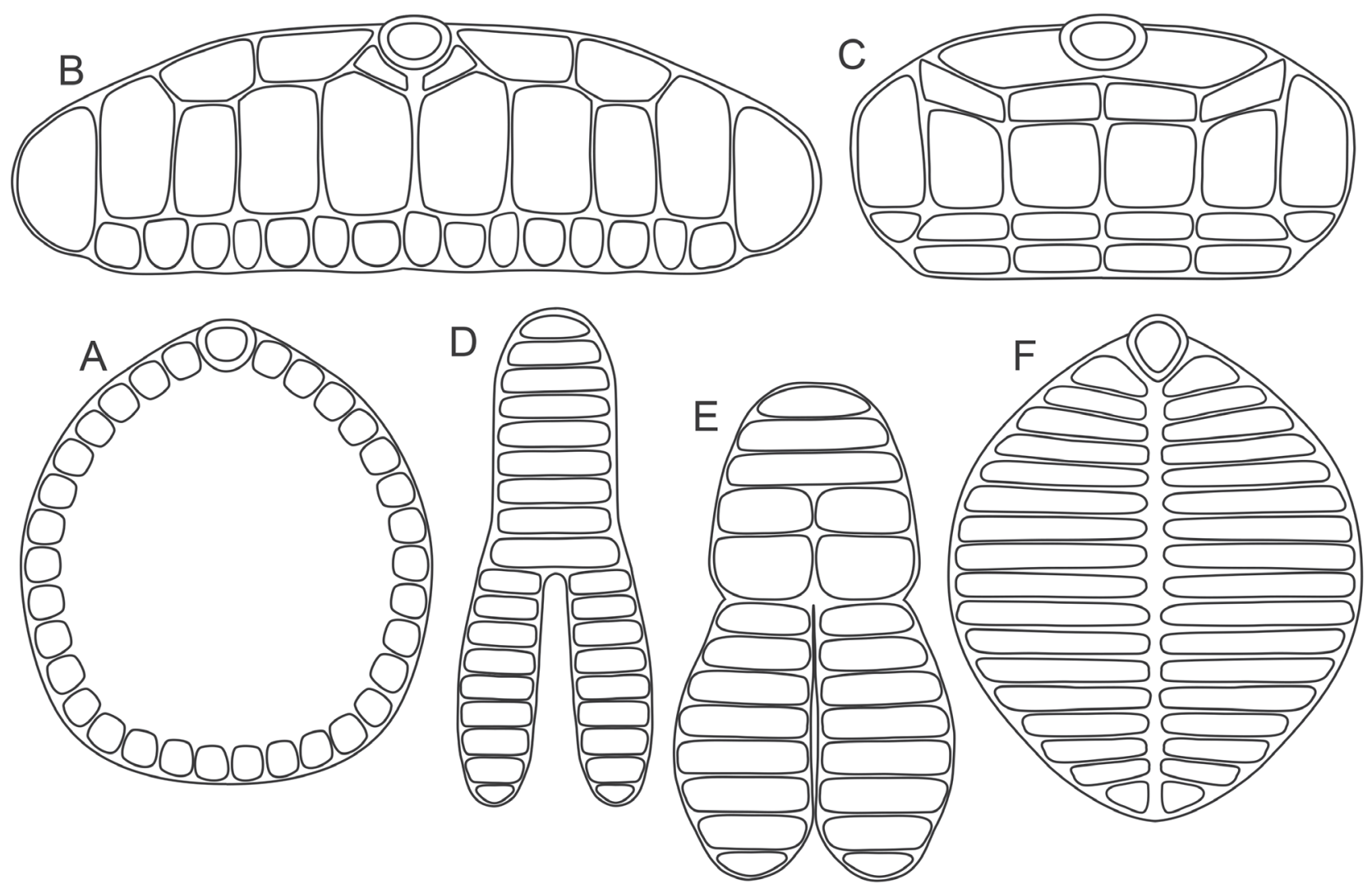

Fig. 10. Schematic illustrations of bothridia of members of the Anthocephaliidae. A - Anthocephalum Linton, 1891; B, C - Barbeaucestus gen. n.: B. jockuschae sp. n. (B) and B. ralickiae sp. n. (C); D, E-Divaricobothrium gen. n.: D. trifidum (Shipley et Hornell, 1905) comb. n. (D) and D. tribelum sp. n. (E); F - Sungaicestus gen. n.

tion of the order Rhinebothriidea by Healy et al. (2009) and in later phylogenetic studies by Caira et al. (2014), Ruhnke et al. (2015) and Marques and Caira (2016). In all of these studies, $R$. kinabatanganensis (as New genus 4 kinabatanganensis) grouped well away from its nominal congeners in a clade with Divaricobothrium tribelum (as New genus 1 n. sp.), two species of Barbeaucestus (as New genus 2 shipleyi and New genus 2 cf. sexorchidum) and the species of Anthocephalum included (Healy et al. 2009, Caira et al. 2014, Ruhnke et al. 2015, Marques and Caira 2016).

As part of our efforts to identify an appropriate generic placement for $R$. kinabatanganensis, we re-examined some of the type slides and the hologenophore of Healy et al. (2009) with light microscopy and also re-examined the scolex of the paratype originally prepared for SEM. In addition, we prepared a whole mount of one additional specimen (LRP 8907) that we were able to locate from the spiral intestine contents of the type host specimen. That work leads us to conclude that the bothridia of the holotype specimen, illustrated in figs. 1 and 5 of Healy (2006b), are especially contracted and recurved, and as a consequence are unrepresentative of the species. We believe the more typical configuration of the scolex is shown in the original scanning electron micrograph presented by Healy $(2006 \mathrm{~b}-$ fig. 18). This image shows bothridia that are approximately as long as they are wide, and the left-most bothridium in particular shows evidence of an apical sucker. The scolex of the whole mount prepared here is relatively relaxed and is much more consistent with the scolex portrayed in SEMs (see Healy 2006b - fig. 18, and Fig. 9 herein). This leads us to believe that the feature interpreted as an anterior loculus by Healy (2006b) is actually an apical sucker, and that the bothridia of the species are generally slightly longer than they are wide (Fig. 10F). Moreover, the two columns of facial loculi appear to be divided by a gap with longitudinal muscle fibres, rather than a septum. Although we were unable to prepare sections owing to the limited available material, it would be interesting to examine sections of this region to determine if the configuration of radial and transverse muscle fibres typical of Rhinebothrium is seen in this species. The original description of the proglottid anatomy of the species is both accurate and fully consistent with that of the other genera of Anthocephaliidae, all of which exhibit columns of vitelline follicles that are wider than long and that are interrupted to some extent by the ovary. In combination with the robust molecular support, these morphological features are sufficient to justify formal establishment of a new genus to house this species as Sungaicestus kinabatanganensis (Healy, 2006) comb. n.

\section{DISCUSSION}

In combination with the work of Marques and Caira (2016) synonymising Pararhinebothroides Zamparo, Brooks et Barriga, 1999 with Anthocephalum, valid genera belonging to the Anthocephaliidae now are Anthocephalum, 
Barbeaucestus, Divaricobothrium, Sungaicestus, and possibly also Cairaeanthus. The proglottid anatomy of the former four genera is relatively uniform. The testes are relatively large and are arranged in approximately two to four columns anterior to the cirrus sac, and the vas deferens extends to the level of the ovary. In many cases the vitelline follicles are arranged in two lateral bands and are interrupted by the ovary. Moreover, the three new genera erected here share vitelline follicles that are conspicuously wider than long. In contrast, the proglottids of Cairaeanthus bear multiple columns of very small testes, restricted to the region of the proglottid anterior to the cirrus sac, small vitelline follicles that encroach on the midline of the proglottid, and a vas deferens that does not appear to extend posterior to the cirrus sac.

However, substantial variation in bothridial morphology exists across the five anthocephaliid genera now recognised (Fig. 10). Most conspicuously, while the bothridia of Anthocephalum (Fig. 10A), Barbeaucestus (Fig. 10B,C) and Sungaicestus (Fig. 10F) bear apical suckers, those of Divaricobothrium (Fig. 10D,E) and possibly also Cairaeanthus do not. However, as noted by Ruhnke et al. (2015), the lack of this feature in the latter genus requires confirmation for it is easy to overlook small apical suckers in taxa with very large numbers of marginal loculi. The posterior margins of the bothridia of the genera bearing apical suckers are not bifid, while those reported to lack apical suckers are bifid. Among the five genera, only Anthocephalum and Cairaeanthus exhibit marginal loculi. Whereas the bothridia of Barbeaucestus are wider than long, those of the other genera are either approximately round, or conspicuously longer than wide.

The molecular phylogenetic analyses of Ruhnke et al. (2015) and Marques and Caira (2016) provide relatively strong support for a sister taxon relationship between Divaricobothrium and Sungaicestus, with Barbeaucestus as their sister taxon and Anthocephalum as the earliest diverging genus of the family. Given the contrast in scolex and proglottid features of Cairaeanthus relative to the other genera of its family, it will be interesting to see the affinities that emerge when this genus is ultimately included in phylogenetic molecular analyses.

Diversity across the five anthocephaliid genera varies substantially. While Anthocephalum currently houses 19 species, Barbeaucestus, Divaricobothrium and Cairaeanthus house only four, two and two species, respectively; Sungaicestus is monotypic. The host associations of the genera lead us to anticipate that the number of species of Anthocephalum, which parasitises species of Dasyatidae, Urotrygonidae and Urolophidae, many of which have never been examined for cestodes, will continue to grow. In fact, preliminary examination of specimens collected from other host species from the Indo-Pacific Ocean supports this notion.

Barbeaucestus is likely to be the next most speciose genus for it is known from Brevitrygon, Neotrygon and Taeniura Müller et Henle. Because these genera are distributed across the dasyatid phylogenetic tree, it seems reasonable that other dasyatid genera will be found to also serve as hosts for Barbeaucestus. The two described and two undescribed species of Divaricobothrium parasitise species of Brevitrygon, Maculabatis and Pateobatis. Given these genera comprise over 25 species, only a subset of which has been examined for cestodes, the existence of additional novelty in the unexamined species is anticipated.

The situation with Cairaeanthus is somewhat puzzling. Kornyushin and Polyakova (2012) described both species from the same species of Dasyatis (i.e. D. pastinaca [Linnaeus]), but we and others have necropsied hundreds of specimens of many species of Dasyatis and related genera but have not seen evidence of this genus, despite the relatively large size of both of its known species (TL of 10.8-31.5 cm for Cairaenthus healyae Kornyushin et Polyakova, 2012 and 5-25.5 cm for Cairaenthus ruhnkei Kornyushin et Polyakova, 2012). However, at this point we would be uncertain how to proceed to discover additional novelty in this group. One thing to consider is that both species of Cairaeanthus were collected in Russian waters, and perhaps the group is confined to cooler areas, which are much more poorly sampled than tropical or subtropical regions.

We are similarly at a loss as to where one might look for additional species of Sungaicestus, which is known only from the freshwater stingray of Borneo, Urogymnus polylepis. Our survey work (Caira and Jensen, unpubl. data), which included necropsies of other species of Urogymnus and also of other species of freshwater dasyatids (i.e. Fluvitrygon oxyrhyncha [Sauvage] and Fluvitrygon signifer [Compagno et Roberts]), yielded no additional species of Sungaicestus.

In terms of the undescribed rhinebothriidean genera that were introduced by Healy et al. (2009), only the taxon they referred to as Rhinebothriinae n. sp. remains to be formally described. That taxon has been referred to as "New genus 11 n. sp. 1" in the subsequent phylogenetic works of Ruhnke et al. (2015) and Marques and Caira (2016), both of which support its recognition as a novel genus.

Acknowledgements. We are grateful to Annie Lim (Fisheries Research Institute, Malaysia), Mabel Manjaji-Matsumoto (Universiti Malaysia, Borneo), Dharmadi (Research Centre for Capture Fisheries, Indonesia), Fahmi (Pusat Penelitian Oseanografi, Indonesia), Loren Caira and Gavin Naylor (College of Charleston) for assisting with collections of elasmobranchs from Borneo. We are also grateful to Michelle Soo (Muzium Zoologi Univeristi Malaya, Kuala Lumpur) for providing images of the holotype specimen of Sungaicestus kinabatanganensis, collections in Malaysian Borneo were conducted under the following permits and research agreements: UPE:40/200/19SJ.924 and UPE:40/200/19SJ.925 from the Economic Planning Unit in Kuala Lumpur; No. JKM 100-24/13/1/223(59) from the Chief Minister's Department, Kota Kinabalu, Sabah, Malaysia; No. SBC-RA-0050-JNC from the Sarawak Biodiversity Centre in Kuching. Collections in Indonesian Borneo (Kalimantan) were conducted under the following permits: Nos. 06252/SU.3/KS/2006 and 3861/SU.3/KS/2007 from LIPI in Jakarta, and 1586/FRP/SM/VII/2008 from RISTEK in Jakarta. We are grateful to Hannah Ralicki for generating $\mathrm{NADH} 2$ data for host identifications. This work was supported in part with funds from NSF MRI award No. 1126100, NSF Biotic Surveys and Inventories award Nos. DEB 0542846, 0542941, 
and 0103640, NSF Planetary Biodiversity and Inventories award Nos. 0818696 and 0818823, and NSF Phylogenetic Systematics award Nos. DEB 1457762 and 1457776. Any opinions, findings, conclusions or recommendations expressed in this material are those of the author(s) and do not necessarily reflect the views of the National Science Foundation.

\section{REFERENCES}

Ball D., Neifar L., Euzet L. 2003: Description of Scalithrium n gen. (Cestoda, Tetraphyllidea), with Scalithrium minimum (Van Beneden, 1850) n. comb., a parasite of Dasyatis pastinaca (Elasmobranchii, Dasyatidae), as type species. Parasite 10: 31-37.

Borsa P., Shen K.N., Arlyza I.S., Hoareau T.B. 2016: Multiple cryptic species in the blue-spotted maskray (Myliobatoidei: Dasyatidae: Neotrygon spp.): an update. C. R. Biol. 339: 417-426.

Caira J.N., Jensen K., Waeschenbach A., Olson P.D., LitTLEWOOD D.T.J. 2014: Orders out of chaos - molecular phylogenetics reveals the complexity of shark and stingray tapeworm relationships. Int. J. Parasitol. 44: 55-73.

Chervy L. 2009: Unified terminology for cestode microtriches: a proposal from the international workshops on cestode systematics in 2002-2008. Folia Parasitol. 56: 199-230.

Euzet L. 1953: Cestodes tétraphyllides nouveaux ou peu connus de Dasyatis pastinaca (L.). Ann. Parasitol. Hum. Comp. 28: 339-351.

Euzet L. 1955: Quelques cestodes de Myliobatis aquila L. Rec. Trav. Lab. Bot., Géol. Zool. Fac. Sci. Univ. Montpellier. Série Zool. 1: 18-27.

Healy C.J. 2006a: A revision of selected Tetraphyllidea (Cestoda): Caulobothrium, Rhabdotobothrium, Rhinebothrium, Scalithrium, and Spongiobothrium. Ph.D. Dissertation. University of Connecticut, Storrs, Connecticut, $382 \mathrm{pp}$.

Healy C.J. 2006b: Three new species of Rhinebothrium (Cestoda: Tetraphyllidea) from the freshwater whipray, Himantura chaophraya, in Malaysian Borneo. J. Parasitol. 92: 364-374.

Healy C.J., Caira J.N., Jensen K., Webster B.L., Littlewood D.T.J. 2009: Proposal for a new tapeworm order, Rhinebothriidea. Int. J. Parasitol. 39: 497-511.

ICZN 1999: International Code of Zoological Nomenclature. Fourth Edition. The International Trust for Zoological Nomenclature, London, $306 \mathrm{pp}$

Kornyushin V., Polyakova T. 2012: Cairaeanthus gen. n. (Cestoda, Rhinebothriidea), with the description of two new species from Dasyatis pastinaca in the Black Sea and the Sea of Azov. Vestn. Zool. 46: e-1-e-18.

Last P.R., Naylor G.J.P., Manjaji-Matsumoto B.M. 2016b: A revised classification of the family Dasyatidae (Chondrichthyes: Myliobatiformes) based on new morphological and molecular insights. Zootaxa 4139: 345-368.

Last P.R., White W.T., NaYlor G. 2016c: Three new stingrays (Myliobatiformes: Dasyatidae) from the Indo-West Pacific. Zootaxa 4147: 377-402.

Received 25 May 2016

Accepted 2016
Last P.R., White W.T., SÉRet B. 2016a: Taxonomic status of maskrays of the Neotrygon kuhlii species complex (Myliobatoidei: Dasyatidae) with the description of three new species from the Indo-West Pacific. Zootaxa 4083: 533-561.

Marques F.P.L., Caira J.N. 2016: Pararhinebothroides - neither the sister taxon of Rhinebothroides nor a valid genus. J. Parasitol. 102: 249-259.

Naylor G.J.P., Caira J.N., Jensen K., Rosana K.A.M., White W.T., LAST P.R. 2012: A DNA sequence-based approached to the identification of shark and ray species and its implications for global elasmobranch diversity and parasitology. Bull. Am. Mus. Nat. Hist. 367: 1-262.

Puckridge M., Last P.R., White W.T., Andreakis N. 2013: Phylogeography of the Indo-West Pacific maskrays (Dasyatidae, Neotrygon): a complex example of chondrichthyan radiation in the Cenozoic. Ecol. Evol. 3: 217-232.

Reyda F.B., Healy C.J., Haslach A.R., Ruhnke T.R., Aprill T.L., Bergman M.P., Daigler A.L., Dedrick E.A., Delgado I., Forti K.S., Herzog K.S., Russell R.S., Willsey D.D. 2016: A new genus of rhinebothriidean cestode from batoid elasmobranchs, with a description of five new species and transfer of two species. Folia Parasitol. 63: 038.

Ruhnke T.R., Caira J.N., Cox A. 2015: The cestode order Rhinebothriidea no longer family-less: a molecular phylogenetic investigation with erection of two new families and description of eight new species of Anthocephalum. Zootaxa 3904: 51-81.

Shipley A.E., Hornell J. 1906: Report on the cestode and nematode parasites from the marine fishes of Ceylon. Report to the Government of Ceylon on the Pearl Oyster Fisheries of the Gulf of Manaar (Herdman), The Royal Society, London, Part V: 4396.

Southwell T. 1912: A description of ten new species of cestode parasites from marine fishes of Ceylon, with notes on other cestodes from the same region. Ceylon Mar. Biol. Rep. 1: 259-278.

Southwell T. 1925: A monograph on the Tetraphyllidea with notes on related cestodes. Mem. Liverpool School Trop. Med. (New Series) 2: 1-368

Williams H.H. 1958: Some Tetraphyllidea (Cestoda) from the Liverpool School of Tropical Medicine. Rev. Suisse Zool. 65: 867-878.

Williams H.H. 1964: Some new and little known cestodes from Australian elasmobranchs with a brief discussion on their possible use in problems of host taxonomy. Parasitology 54: 737-748. Yamaguti S. 1934: Studies on the helminth fauna of Japan. Part 4. Cestodes of fishes. Jpn. J. Zool. 6: 1-112.

Cite this article as: Caira J.N., Healy C.J., Marques F.P.L., Jensen K. 2017: Three new genera of rhinebothriidean cestodes from stingrays in Southeast Asia. Folia Parasitol. 64: 008. 